\title{
Deliberate premarket underpricing and aftermarket mispricing: New insights on IPO pricing
}

\begin{abstract}
We decompose initial returns into deliberate premarket underpricing and aftermarket mispricing using Stochastic Frontier Analysis. We model deliberate underpricing as a function of proxies of information asymmetry surrounding IPO value between market participants. Equity retained is an unlikely signalling mechanism to convey IPO value to outside investors through deliberate premarket underpricing. The presence of lock-in agreements, underwriter fees, number of uses of proceeds, and venture capital or private equity backing have positive impacts on deliberate premarket underpricing. Demand for firms' capital also explains deliberate premarket underpricing, whereas new issues market conditions have no impact. All these factors are found to explain a significant fraction of the variations in our deliberate underpricing estimates. Deliberate underpricing is the more dominant component that makes up initial return when compared to the fraction of aftermarket mispricing. We attribute aftermarket mispricing to trading volume in IPO shares on the first day, price adjustment between the filing price range and the offer price, and offer size. Equity retained explains the aftermarket mispricing rather than the deliberate premarket underpricing in contradiction to the signalling argument. More reputable underwriters are likely to provide price support in the early aftermarket, whereas we observe no impact on deliberate premarket underpricing.
\end{abstract}

Keywords: Initial IPO return, deliberate premarket underpricing, aftermarket mispricing

JEL: G12, G23, G32 


\section{Introduction}

An initial public offering (IPO) is the first sale of shares by a private company to the public on a securities exchange. The valuation of shares of an unlisted company is challenging due to the absence of current market prices and trading history. Information asymmetry between market participants surrounding the value of these shares leaves the new issues market subject to Akerlof's (1970) classic adverse selection problem which manifests itself in persistent average initial return across capital markets. ${ }^{1}$ Figure 1 documents average initial return and the persistence of the phenomenon as well as the number of U.S. IPOs by quarterly intervals from the first quarter of 1980 to the last quarter of 2012. The diagram illustrates the cyclicity in persistent initial return as well as the number of IPOs during the sample period.

\section{Figure 1: Average initial return and number of US IPOs by quarterly intervals, 1980-2012}

Average initial return is the equally-weighted mean of the percentage change from the offer price in the premarket to the aftermarket price. Quarterly data on initial return and the number of IPOs are compiled from monthly observations available from Jay Ritter's website (http://bear.warrington.ufl.edu/ritter). ${ }^{2}$

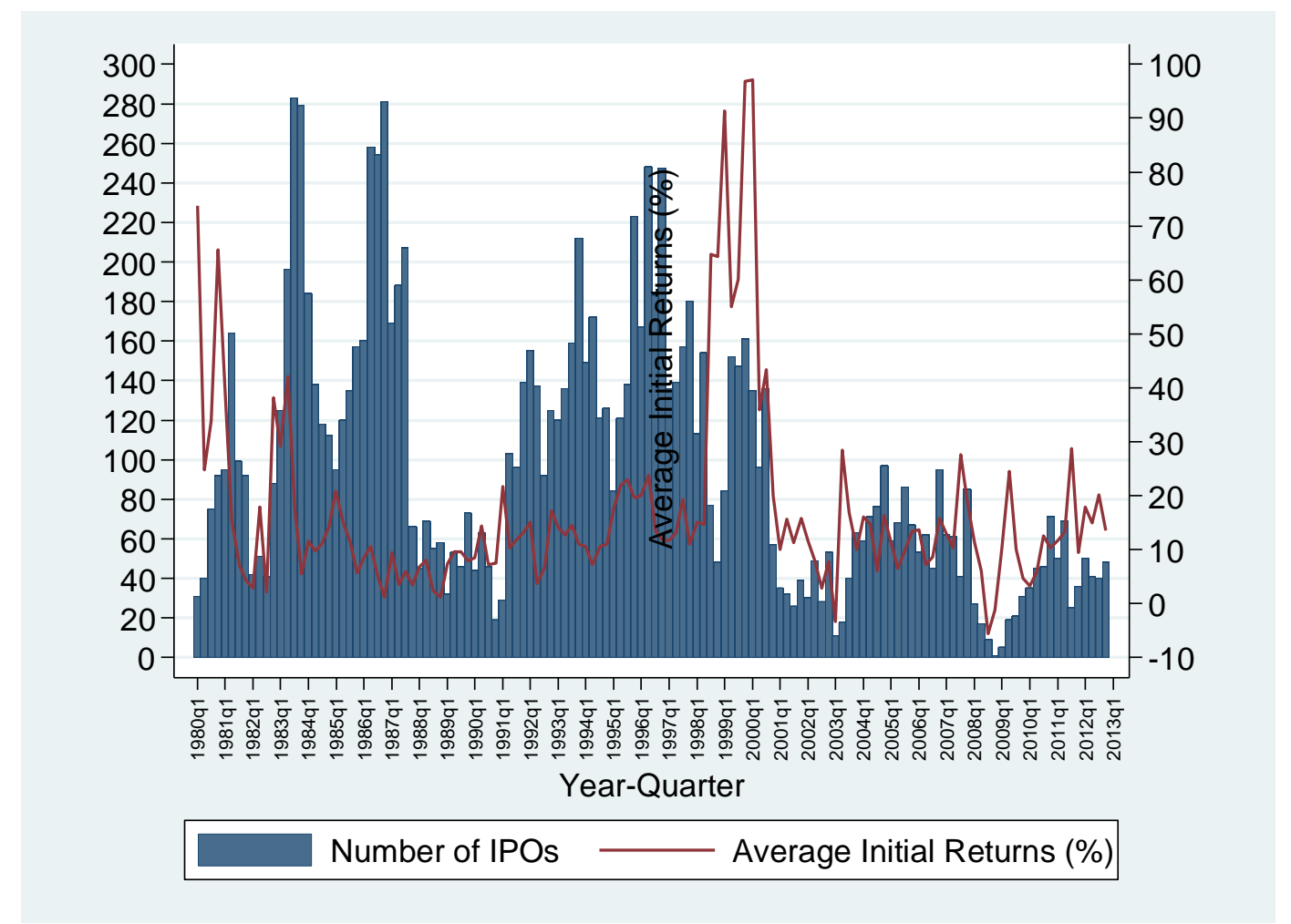

\footnotetext{
${ }^{1}$ Initial return is the percentage change from the offer price to the market price in the aftermarket. See, for example, Table 1 in Banerjee, Dai, and Keshab (2011), Table 6 in Ritter (2003), and Jay Ritter's web site (http://bear.warrington.ufl.edu/ritter) that has regular updates of Table 1 in Loughran, Ritter, and Rydqvist (1994).

${ }^{2}$ This is the URL address for all future references to Jay Ritter's IPO website.
} 
The literature offers three main explanations for persistent average initial return: deliberate underpricing in the premarket (henceforth deliberate underpricing), mispricing in the early aftermarket as a result of trading activity, and underwriter price stabilization in the early aftermarket. ${ }^{3}$ The first strand of the literature ascribes initial return to deliberate underpricing as the outcome of information asymmetry surrounding IPO value among participants in the premarket. For example, Grinblatt and Hwang (1989), Welch (1989), and Allen and Faulhaber (1989) use deliberate underpricing as a costly and difficult to imitate signal in which firm insiders transmit positive information on firm value to outside investors. Baron (1982) explains deliberate underpricing and the persistence of the phenomenon as the outcome of a principal-agent conflict in which the issuing firm (principal) cannot directly observe the marketing and distribution efforts of the underwriter (agent). The underwriter can thus induce the issuing firm to agree to a relatively low offer price. Rock's (1986) model assumes that IPOs have to be, on average, underpriced to compensate less-well informed investors for a winner's curse ${ }^{4}$ problem and to induce them to participate in the new issues market.

The second strand of the literature assumes that IPOs are priced at their intrinsic value in the premarket and attributes initial return to trading activity in the early aftermarket as a result of, for example, overoptimistic investors and their valuations. For example, Aggarwal and Rivoli (1990) focus on fads in the IPO market whereby new issues are possibly not priced at intrinsic values in early aftermarket trading. Ritter (1991) and Loughran and Ritter (1995) explain initial return as a consequence of investors being overoptimistic about firm value which creates excess demand in shares, pushes up prices and leads to high initial return in the aftermarket. Friesen and Swift (2009) attribute initial return to investor overreaction at the time of the IPO before prices revert back to fundamental firm value. Aggarwal $(2000,2003)$, Ellis, Michaely, and O'Hara $(2000,2002)$ and Ellis (2006) find evidence that flipping is not solely responsible for high trading volumes in the early aftermarket. $77 \%$ of trades are investor-motivated, while interdealer trading accounts for the remaining 23\%. Chahine (2007) report a positive relationship between the share demand-to-offer ratio in the premarket and the trading volume in the aftermarket.

The third strand of the literature attributes positive average initial return to underwriter price support. The price support leads to a censoring of the return distribution and the spurious impression of persistent average initial return. For example, Ruud (1993), Asquith, Jones and Kieschnick (1998) and Aggarwal $(2000,2003)$ find that underwriters stabilize the aftermarket prices at the offer price which results in very few IPO stocks being overpriced.

\footnotetext{
3 'Premarket' indicates the time leading up to the IPO date (stock market flotation), whereas 'aftermarket' refers to the time once trading commences in the stock market.

${ }^{4} \mathrm{~A}$ winner's curse arises here because less-well informed investors obtain a higher proportion of overpriced IPOs because better-informed investors only apply for underpriced new issues.
} 
On the one hand, existing research explains positive average initial return and its persistence as a combination of deliberate underpricing and aftermarket mispricing as a result of trading in the early aftermarket. The most commonly held view is that deliberate underpricing is the main contributor towards persistent average initial return (Grinblatt and Hwang, 1989; Welch, 1989; Allen and Faulhaber, 1989; Baron, 1982; and Rock, 1986). On the other hand, empirical studies do not distinguish between deliberate underpricing and aftermarket mispricing when testing competing theories. ${ }^{5}$ However, the lack of such a distinction is not surprising. Disentangling deliberate underpricing and aftermarket mispricing from initial return is difficult. To do so requires a 'fair' offer price, which is not directly observable, in addition to the offer price and the closing share price in the aftermarket.

In this paper, we identify this 'fair' offer price using stochastic frontier analysis (henceforth SFA), which estimates the maximum achievable offer price from given issuing firm attributes, deal characteristics, third-party certification, and IPO market conditions. SFA assumes the existence of an efficient pricing frontier such that the offer price falls onto or below the estimated frontier due to a systematic one-sided error to account for pricing inefficiency plus a random error term. The one-sided error term allows calculating an inefficiency measure to uncover deliberate underpricing from the maximum offer price that lies on the efficient frontier. Our approach builds on existing studies in this area, such as for example, Hunt-McCool, Koh and Francis (1996), Koop and Li (2001), Francis and Hasan (2001), Chen, Hung and Wu (2002), and Chan, Wu and Kwok (2007).

Compared to these earlier studies, our stochastic IPO pricing frontier uses an extended set of pricing factors to estimate the maximum (fair) achievable offer price. These pricing factors are the primary drivers of equity value and originate from standard finance theory. They include, for example, proxy variables for expected cash flows, cost of capital, and future growth prospects. These value drivers determine the efficient frontier of fair offer prices. An incomplete set of pricing factors could lead to less accurate estimates of fair offer prices and hence less precise estimates of deliberate underpricing. Our estimation of the pricing frontier simultaneously controls for what we call underpricing factors to explain variations in deliberate underpricing. For this, we use a set of variables drawing from existing theories on information asymmetry surrounding IPO value among new issues market participants such as, for example, Grinblatt and Hwang (1989), Welch (1989), Allen and Faulhaber (1989), Baron (1982), and Rock (1986). Finally, after having identified deliberate underpricing, we uncover aftermarket mispricing, which allows us to explain aftermarket mispricing with the help of proxy measures that capture trading activity in the early aftermarket. We argue that IPO market value partly depends on this trading activity and use relevant proxy variables from earlier studies such as, for example, Chen, Hung and Wu (2002), Ellis (2006), and Agarwal (2003).

\footnotetext{
${ }^{5}$ For an overview of the empirical literature see, for example, Jenkingson and Ljungqvist (2001).
} 
We hence make several distinct contributions to the literature in light of the ongoing debate on whether deliberate underpricing or aftermarket mispricing is the dominant explanation of observed initial return. First, we add to the literature on the use of SFA as a tool for differentiating deliberate premarket underpricing from initial return. The use of SFA to measure deliberate premarket underpricing in U.S. IPOs was first proposed by Hunt-McCool, Koh and Francis (1996), with later applications by Koop and Li (2001) and Francis and Hasan (2001). ${ }^{6}$ By estimating deliberate underpricing, we can test whether initial returns is primarily driven by deliberate underpricing or by aftermarket mispricing as a result of early trading in the aftermarket.

Second, using a more refined measure, we test the commonly held view that information asymmetry surrounding IPO value among new issues market participants explains variations in deliberate underpricing. While existing studies have tested the explanatory power of information asymmetry theories, these have been conducted using initial return, which is a combination of deliberate underpricing and aftermarket mispricing. By constructing a more refined measure of deliberate premarket underpricing, we are able to directly test how it is affected by variables proxying information asymmetry, and hence improve on these earlier studies. We test the effect of information asymmetry on deliberate underpricing by exploiting developments in the SFA literature on the modelling of exogenous factors affecting the distance from the frontier. For this, we use the conditional variance model proposed in Kumbhakar and Lovell (2000), simultaneously estimating the stochastic pricing frontier alongside the determinants of deliberate underpricing.

Finally, once we have estimated the deliberate underpricing component, we recover an estimate of aftermarket mispricing and then test whether it can be explained primarily by trading activity. Accordingly, we regress this aftermarket mispricing component of initial return against proxies of trading activity, allowing us to test the hypothesis that IPO market value partly depends on the trading activity in the early aftermarket.

\section{Disentangling deliberate premarket underpricing and aftermarket mispricing}

The central contribution of this paper is to disentangle deliberate underpricing in the premarket and aftermarket mispricing from initial returns, and test whether variations in these components can be explained by existing theories. Differentiating these components from observed initial returns relies crucially on being able to estimate a fair offer price for each IPO. We estimate the fair offer price using SFA, a benchmarking econometric technique that has seen numerous applications since it was originally proposed independently by Aigner, Lovell and Schmidt (1977) and Meeusen, and van de Broeck (1977). A few studies have used SFA as a tool to measure deliberate underpricing in IPOs. Hunt-McCool, Koh and Francis (1996) is the first study to apply SFA in IPO pricing. They use firm characteristics, industry dummy variables and market sentiment to estimate

\footnotetext{
${ }^{6}$ To the best of our knowledge these are the only studies using U.S. data.
} 
the fair offer price and deliberate underpricing on a sample of 1,035 US IPOs between 1975 and 1984. In their study, offer price is related to a number of pricing factors, including book value, sales, number of risks disclosed in the prospectus, underwriter commission rates, equity retained by preIPO owners, firm age, offer proceeds from issue, and price-earnings ratio. The analysis divides the sample into hot issue and non-hot issue periods to capture market sentiment, whereby time intervals with relatively high initial return and large numbers of IPOs are deemed to be hot new issues markets. The authors estimate deliberate underpricing at $8.9 \%$ and $8.0 \%$ respectively for both hot-issue and non-hot issue markets. These estimates compare to observed average initial return of $10.28 \%$ and $9.12 \%$ respectively. In a further analysis, the authors regress initial return (based on the first available aftermarket bid price) against the estimated deliberate underpricing component and find a significant positive correlation only for the hot issues period. They conclude that deliberate underpricing explains only a fraction of the observed initial return during hot issue periods.

Francis and Hasan (2001) use SFA to compare the underpricing of venture capital backed with non-venture capital backed IPOs to test existing evidence in the literature that suggests the degree of initial return depends on venture capital (VC) backing. The offer price correlates with firm size, offer proceeds, the ratio of underwriter fee to offer size, underwriter reputation, equity retention by pre-IPO owners, and NYSE as the place of flotation. The authors estimate a combined frontier on a sample of 843 U.S. IPOs between 1990 and 1993, as well as separate frontiers for VC backed and non-VC backed new issues. Estimates of the average deliberate underpricing is $29.1 \%$ for the pooled sample, while the figures for VC backed and non-VC backed IPOs are $35.3 \%$ and 27.1\% respectively. A follow up regression shows a positive and statistically significant association between initial return and deliberate underpricing. Disaggregating these estimates into size deciles suggests that deliberate underpricing decreases with increased firm size.

Koop and Li (2001) apply Bayesian SFA to investigate the valuation of a pooled sample of 2,969 IPOs and 3,771 seasoned equity offerings (SEOs) in the U.S. between 1985 and 1998. Their study departs from Hunt-McCool, Koh and Francis' (1996)'s approach in two ways. Firstly, Koop and Li (2001) argue that SFA using IPOs only is likely to result in these issues being more efficiently priced which leads to underpricing being underestimated. Therefore, Koop and Li (2001) recommend constructing the pricing frontier from both IPOs and SEOs. This approach is more likely to place SEOs closer to the frontier, while IPOs would be further away from the frontier, resulting in higher levels of IPO underpricing. Koop and Li (2001) therefore analyse whether IPOs are underpriced per se in relation to SEOs, rather than whether some IPOs are underpriced more than other new issues. Secondly, they use market capitalization as an aggregate measure of firm value rather than offer price per share which depends on the number of shares in free float. Another contribution of their study involves the explicit separation of pricing from underpricing factors in estimation. The 
pricing factors affect the frontier and include net income, revenue, earnings per share, total assets, debt, and underwriter fees. The underpricing factors include dummy variables to capture SEOs, hot and cold new issues periods, NBER peak issue months, NYSE new issues, multiple offers made by issuers, and the top five lead managers acting as underwriters ranked by market share. The results reveal a positive association between firm value, net income, revenues, total assets, and underwriter fees, while the correlation between firm value and leverage is negative. Firms operating in industry sectors with higher earnings potential such as, for example, chemical products, computers, electronic equipment, scientific instruments and communications also have higher valuations. Among the underpricing factors, only the dummy variables on SEO and multiple offers made are positive and statistically significant. IPOs are, on average, found to be undervalued by between $25 \%$ and $30 \%$, while SEOs, which drive the frontier, are undervalued by at most $5 \%$.

Chen, Hung and $\mathrm{Wu}$ (2002) apply SFA to measure deliberate premarket underpricing and aftermarket mispricing for a sample of 196 Taiwanese IPOs spanning the period 1985 to 1995. These authors use as pricing factors firm age, offer proceeds, equity retained by pre-IPO owners, earnings per share, total assets, and the industry price-earnings ratio. The study reports an average deliberate premarket underpricing of $7.46 \%$ for the pooled sample, while the figures for hot and cold new issues periods are 7.16 and $7.72 \%$, respectively. The authors fail to find any significant relationship in a regression of adjusted initial return ${ }^{7}$ on deliberate underpricing. In a further analysis, they investigate whether noisy trading in the aftermarket explains initial return. Noisy trading is proxied by variables measuring the probability of receiving an allocation of IPO shares, the proportion of shares retained by pre-IPO owners, and firm size. All three variables have a positive and significant association with the 30-day adjusted initial return. In a further test, the authors investigate whether IPOs suffer from poor returns in the long term after noisy trading activities subside but could not find evidence of a positive correlation in a regression of 3 year holding returns on variables proxying noisy trading.

Chan, Wu and Kwok (2007) use SFA to study the impact of global offer prices on the pricing of U.S. IPOs using a sample of 2,307 new issues between 1986 and 1998. The study uses both pricing factors and underpricing factors to estimate the efficient frontier of offer prices. Pricing factors comprise earnings per share, the standard deviation of the firm's first 120 daily returns, offer price revision, gross spread as a percentage of offer size, the rank of the lead underwriter, a spin-off dummy variable, dummy variables indicating the stock exchange (NYSE, AMEX, NASDAQ), market capitalization, and industry sector dummy variables. The underpricing factor is a dummy variable capturing global IPOs. The estimation follows the Batesse and Coelli (1995) conditional mean

\footnotetext{
7 These are cumulative seven day (as well as thirty day and three year) returns less the estimated deliberate premarket underpricing component.
} 
model, revealing that purely domestic IPOs are underpriced by 3.1 percentage points more than global IPOs.

Peng and Wang (2007) employ SFA and focus on the impact of offer methods on offer prices using a sample of 647 Taiwanese IPOs between 1996 and 2003. They use a two-stage approach to estimating underpricing of IPOs and its determinants. In the first stage, they estimate a stochastic frontier using earnings per share, total assets, firm age, debt ratio, and proportion of stocks retained by pre-IPO owners at flotation as pricing factors. The first stage is estimated by the method of moment approach. In the second stage, the authors run a regression of the estimates of underpricing (from the first stage) on a number of determinants. The underpricing factors include offer methods, return and volatility of market index, probability of stock allocation in oversubscribed offerings, offer size, amount of sales, level of earnings management, underwriter reputation, auditor reputation, industry dummy variables, and stock market dummy variables. A key finding is that the auction method reduces the average underpricing when compared to fixedprice offerings. In addition, the study reports that greater earnings potential, less risk or offers with less information asymmetry have lower underpricing.

Finally, in a recent paper, Luo and Ouyang (2014) use Bayesian SFA to analyse the pricing efficiency of 379 IPOs in the ChiNext market ${ }^{8}$ between 2009 and 2014. They base their input variables on fundamentals of issuers, information asymmetry surrounding IPO value, offer characteristics, and market environment. The authors claim that underwriters are predominantly responsible for pricing inefficiency in the ChiNext market.

Although all the above studies use SFA to measure deliberate premarket underpricing, it is noteworthy that, with the exception of Koop and Li (2001), there is no study that explicitly separates out pricing factors and controls for underpricing factors in the IPO pricing frontier. In addition, none of the existing studies attempts to relate the deliberate premarket underpricing to proxy variables that capture information asymmetry between market participants, which is one of the dominant explanations of persistent average initial return. Existing studies which use such proxy variables use them as part of the pricing factors, instead of treating these proxy variables as affecting the degree of deliberate underpricing.

Our paper thus makes several contributions to the existing literature. We separate out pricing factors and underpricing factors and control for these in the IPO pricing frontier. The efficient pricing frontier enables us to determine the degree of deliberate premarket underpricing. We include commonly used proxy variables that reflect information asymmetry between market participants to explain variations in deliberate premarket underpricing. Disentangling the

\footnotetext{
${ }^{8}$ ChiNext was launched in October 2009 in China to provide a new financing platform to raise capital for small- and medium-sized enterprises.
} 
deliberate premarket underpricing from the observed initial return enables us to also examine whether trading activity in the early aftermarket can explain the residual mispricing component.

\section{Offer price, pricing factors and underpricing factors}

In line with most of the earlier studies quoted above, the offer price per share is the dependent variable in our stochastic frontier. The independent variables are pricing factors, which are primary drivers of equity value and originate from standard finance theory. Estimates of inefficiency reflect deliberate premarket underpricing and variations in these are related to proxy variables that capture various types of information asymmetries surrounding IPO value between participants in the new issues market.

\subsection{Pricing factors}

Estimating expected cash flow, cost of capital and growth opportunities to value the equity of IPOs is nontrivial. Relatively little is known about the past performance of IPO firms and their future prospects. Instead of attempting to estimate expected cash flow, cost of capital and growth opportunities directly, we use several proxy measures.

We use earnings before interest, tax, depreciation and amortization (EBITDA) in the most recent twelve-month period before going public as an input into our valuation model even though finance theory advocates using cash flows. EBITDA is a better predictor of future operating cash flows than current operating cash flows as evidenced in previous research. Teoh, Welch and Wong (1998) find that earnings better reflect a more long-term stream of wealth creation than cash flows that are subject to higher annual volatility. Also, IPO prospectuses do not normally disclose objective (audited) cash flow forecasts and estimates of cost of capital. In the long-term, earnings converge to cash flows. We rely on EBITDA as opposed to earnings per share (EPS) to circumvent claims that IPO firms raise reported EPS by manipulating discretionary accounting accruals before going public. Teoh, Welch and Wong (1998) find that excessive earnings management can lead to higher initial valuations, followed by long-run underperformance. Indeed, Koop and Li (2001) confirm that EPS is not an important pricing factor in IPO valuation. In a more recent study, Aggarwal, Bhagat and Rangan (2009) therefore use EBITDA in their valuation model as opposed to earlier studies that rely on EPS (Koop and Li, 2001; Chen, Heng and Wu, 2002; Peng and Wang, 2007; Luo and Ouyang, 2014).

Industry sector dummy variables take account of differences in the cost of capital and business risk across industry sectors. We classify the firms into 12 industry sectors using the two-digit SIC level, in line with Koop and Li (2001). In the absence of any stock market trading in the period leading up to flotation and any disclosure of objective (audited) estimates of the cost of capital in 
the flotation prospectus, we use these industry sector dummy variables to reflect the divergent business risk.

Three sets of proxy measures capture earnings potential and growth opportunities that are key contributors to IPO value. The first proxy measure is a dummy variable that takes account of negative earnings in the accounting period before going public. Aggarwal, Bhagat and Rangan (2009) argue that negative earnings represent valuable future growth opportunities rather than current profitability. In their study, firms with higher negative earnings have higher valuations, which would appear to be counter-intuitive at first glance from a profitability point of view. The amount of $R \& D$ spending in the accounting period before going public is the second proxy measure. Aggarwal, Bhagat and Rangan (2009), Hertzel, Huson and Parrino (2012) and Deeds, Decarolis and Coombs, (1997) use R\&D investment to proxy for growth opportunities and hence value driver. Our industry sector dummy variables discussed above are the third proxy measure. They take account for differences in earnings potential and growth opportunities across various industries. HuntMcCool, Koh and Francis (1996), Koop and Li (2001) also control for industry sector affiliation in their stochastic frontier model.

We use book value of assets in the most recent twelve-month accounting period before going public as the lower bound for IPO value. Hunt-McCool, Koh and Francis (1996), Koop and Li (2001), Chen, Hung and Wu (2002), and Peng and Wang (2007) also include the book value of assets as a pricing factor in their value estimations.

Finally, we use financial leverage, measured by long-term debt divided by book value of assets in the accounting period before going public as proxy for risk. Firms with higher financial distress have a greater chance of going bankrupt and hence should have lower valuations. Koop and Li (2001) and Peng and Wang (2007) corroborate a negative relationship between leverage and firm value.

\subsection{Underpricing factors}

Existing research explains persistent average initial return as the outcome of information asymmetry on IPO value between issuers, underwriters and different investor segments. Our underpricing factors reflect these information asymmetries at various stages of the IPO valuation process.

We include sales and age of the issuing firm to control for ex ante uncertainty surrounding IPO value. These variables measure how established a firm is. Smaller firms with lower growth in sales and shorter operating history suffer from greater ex ante uncertainty surrounding IPO value. Greater ex ante uncertainty forces issuers to underprice IPOs to compensate uninformed investors for an adverse selection problem. Uninformed investors end up with a higher proportion of 
overpriced issues than informed investors who only apply for underpriced IPOs (Rock, 1986; Beatty and Ritter, 1986). Accordingly, we use the amount of sales in the most recent twelve-month accounting period before going public. Hunt-McCool, Koh and Francis (1996), Koop and Li (2001), Peng and Wang (2007), and Aggarwal, Bhagat and Rangan (2009) report a positive association between sales and IPO value. Firm age, measured in years between the firm's date of foundation and the IPO date, has a positive association with IPO value according to the findings of HuntMcCool, Koh and Francis (1996).

We use equity retained by pre-IPO shareholders after the issue, proceeds raised at the disposal of the issuing firm, the commitment of pre-IPO shareholders not to sell additional shares immediately in the aftermath of the issue, and underwriting fees as proxy measures for ex ante uncertainty surrounding the deal characteristics. It is not unreasonable to assume that firm insiders know more about future firm prospects than outside investors (Akerlof, 1970). Firm insiders can transmit costly and difficult to imitate signals to convey firm value to outside investors (Spence, 1973). We use Leland and Pyle's (1977) equity retained by pre-IPO shareholders in the post-IPO firm jointly with proceeds at the disposal of the issuer as signal in which firm insiders transmit information on firm value to outside investors. The impact of these signalling variables on the stochastic frontier price is inconclusive. Some studies find a relationship whereas other studies report insignificant results or omit these signalling variables altogether. Our study therefore seeks to re-examine the importance of these signalling variables. The proportion of equity retained is a costly signal because owners forgo the possibility of achieving diversification of their personal investment portfolio. Various conceptual frameworks use equity retained as signal to reduce information asymmetry surrounding firm value (Grinblatt and Hwang, 1989; Welch, 1989; Allen and Faulhaber, 1989). Hunt-McCool, Koh and Francis (1996) report a positive relationship between equity retained and estimated offer price. Van der Goot and Roosenboom (2005) show a positive association between management stock ownership and market capitalization. Aggarwal, Bhagat and Rangan (2009) find a negative relationship between insider retention and offer value. Chen, Hung and Wu (2002) do not find a statistically significant relationship. Koop and Li (2001) and Luo and Ouyang (2014) omit equity retention as a signalling variable in their stochastic frontier model.

The amount of IPO proceeds at the disposal of the issuing firm is an effective signal, perhaps of investment plans, for example. Studies normally use proceeds at the disposal of the issuing firm in conjunction with equity retained by pre-IPO owners as a joint signal of firm value (Downes and Heinkel, 1982; Ritter 1984b; Kim and Weisbach, 2008). Hunt-McCool, Koh and Francis (1996) report a positive relationship between proceeds and offer price, while Peng and Wang (2007) report a negative association between the amount of money raised and pricing inefficiency. Koop and Li (2001), Chen, Hung and Wu (2002) and Aggarwal, Bhagat and Rangan (2009) omit proceeds as a signalling variable in their stochastic frontier models. 
We use a dummy variable to account for the presence of lock-in agreements. The impact of lockin agreements on prices in a stochastic frontier framework awaits investigation. A lock-in agreement is a commitment that prohibits firm insiders from selling shares in the aftermarket for a specified period. Demand in IPO shares with a lock-in agreement should be higher than offers without such an agreement. Investors are more willing to buy an IPO knowing that they have a reduced moral hazard problem during the period in which firm insiders cannot sell their equity stakes. This argument is in line with the findings of Brav and Gompers (2003) and Arthurs, Busenitz, Hoskisson and Johnson (2009). The supply of tradable shares increases only following the lock-in expiration, which could potentially have a negative impact on share prices (Bradley, Jordan, Ha-Chin and Roten, 2001; Field and Hanka, 2001). In the US, the lock-in period can be as short as 90 days and as long as two years.

We use underwriting expenses as a proxy for the riskiness of an IPO. Underwriter compensation is likely to be a function of information costs and deal characteristics (Hughes, 1986). Fees will be higher for those IPOs about which relatively little public information is available such as, for example, less well-established and younger firms. Accordingly, various studies use underwriter expenses as proxy for ex ante uncertainty surrounding the deal characteristics. In a stochastic frontier framework, Hunt-McCool, Koh and Francis (1996) report a negative association between underwriter compensation and estimated offer price. In contrast, Koop and Li (2001) report a positive relationship between fees and market capitalization at the offer price. Neither of the two studies simultaneously control for underwriting fees and underwriter reputation. Chen, Hung and Wu (2002) and Aggarwal, Bhagat and Rangan (2009) do not take account of underwriting expenses in their analysis. We therefore provide further evidence on the simultaneous effect of underwriter fees and reputation to shed light on earlier mixed findings.

We use logarithm of one plus the number of uses of IPO proceeds disclosed in the flotation prospectus as proxy of ex ante uncertainty surrounding firm value. This measure is to some extent endogenous and hence we simultaneously control for deal characteristics. The number of uses of proceeds is a function of offer size, the proportion of the proceeds at the disposal of the firm and the proceeds going to selling pre-IPO shareholders. Therefore, a simple count of the number of uses of proceeds without controlling for offer size and the proportion of funds at the disposal of the issuer is unlikely to be informative and can lead to contradictory findings in a cross-sectional analysis. For example, Beatty and Ritter (1986) report a positive association between the number of uses of proceeds and underpricing. In contrast, Ljungqvist and Wilhelm (2003) and Leone, Rock and Willenborg (2007) find that more specific disclosure leads to lower underpricing. The absence of the number of uses of proceeds from studies using SFA to explain deliberate underpricing allows us to extend the literature. 
We use underwriter reputation, private-equity and/or venture capital backing as third-party certification of ex ante uncertainty to endorse IPO value. Underwriter reputation employs Loughran and Ritter's (2004) ranking of investment banks in tombstone advertisements of IPO prospectuses. Regular updates on underwriter reputation are available from Jay Ritter's web site. These updates allow for variation in underwriter reputation across different investment banks and time periods. Reputation capital and the corresponding ranking can improve, deteriorate or remain unchanged. We believe that tombstone rankings are perhaps the most meaningful indicators of reputation capital. Firstly, the rankings in tombstone advertisements most closely reflect underwriter activity in the IPO market. Underwriter rankings have not previously been used in SFA applications to explain deliberate premarket underpricing. Secondly, market share (see, for example, Megginson and Weiss, 1991; Beatty, Bunsis and Hand, 1998; Habib and Ljungqvist, 2001; Chemmanur and Paeglis, 2005), is a more ambiguous definition of reputation since it involves a trade-off between using aggregate number of IPOs or aggregate offer size as the basis for any rankings. Thirdly, underwriter fees (see, for example Booth and Smith, 1986; Hunt-McCool, Koh and Francis, 1996; Koop and Li, 2001) may not be a representative proxy of reputation capital given the sample period under investigation. Hsuan-Chi and Ritter (2000) provide evidence that underwriting fees are clustered around 7\% for firm-commitment offers during the late 1990s, which overlaps with our sample period. Any deviation from $7 \%$ is therefore likely to be associated with differences in the risk of a deal rather than a reflection of the reputation capital of underwriters.

We employ a dummy variable to capture IPOs with private equity backing and/or venture capital backing. Our study is the first analysis to test the impact of private equity and/or venture capital backing on the deliberate premarket underpricing in a stochastic frontier context. Disentangling the relative impact of private equity backing and/or venture capital backing on deliberate underpricing is important because of the mixed results reported in the literature explaining initial return. On the one hand, some studies claim that private equity backing and/or venture capital backing endorses firm value and reduces initial return (see, for example, Barry, Muscarella, Peavy and Vetsuypens, 1990; Megginson and Weiss, 1991; Lerner, 1994; Brav and Gompers, 1997; Nahata, 2008; Arthurs, Busenitz, Hoskisson and Johnson, 2009; Bartling and Park, 2009; Krishnan, Ivanov, Masulis and Singh, 2011; Nanda and Rhodes-Kropf, 2013). Furthermore, younger venture capital backed IPOs have, on average, higher initial return than those IPOs that have more established venture capital backing (Gompers, 1996). On the other hand, Liu and Ritter (2011) report that venture capital backed IPOs have higher initial return when they have coverage from more reputable analysts.

We use aggregate IPO number and aggregate average initial return to take account of new issues market conditions at the time of flotation. Data on aggregate IPO number and aggregate average initial return are available from Jay Ritter's web site. We follow Yung, Çolak and Wei's (2008) 
approach to discriminate between 'hot', 'cold' and 'normal' new issues market activity. 'Hot market activity' is when the number of IPOs in a quarter is $50 \%$ greater than the three-monthly moving average. 'Cold market activity' is when the number of IPOs in a quarter is $50 \%$ smaller than the three-monthly moving average. All other quarters fall into the category of 'normal' new issues market activity. Our analysis is the first study to include new issues market conditions in a stochastic frontier framework to test the impact on deliberate underpricing. We include aggregate IPO number and aggregate average initial return because Lowry (2004), Loughran and Ritter (2004), Brailsford, Heaney and Shi (2009), and Yung, Çolak and Wei (2008) identify two stylised facts about these measures. Firstly, the number of IPOs and average initial return are highly autocorrelated. Secondly, the correlation between the two series is positive.

Finally, we use the change in real private nonresidential fixed investment as proxy for private firms' demand for capital. We use the same approach as above to discriminate between 'hot', 'cold' and 'normal' periods for demand for capital. The impact of this variable on deliberate underpricing in a stochastic frontier analysis awaits investigation. Yung, Çolak and Wei (2008) measure investment opportunities directly via the change in real private nonresidential fixed investment rather than indirectly via financial statements at firm level to infer the value of investment opportunities. Firm attributes or deal characteristics do not sufficiently differ to fully account for the IPO cycles (Ritter, 1984a; Lowry and Schwert, 2002; Loughran and Ritter, 2004). Yung, Çolak and Wei (2008) demonstrate that exogenous shocks to the value of private firms' investment opportunities can lead to more active IPO markets with more low quality issuers going public than the average pre-shock issuing firm. These exogenous shocks can therefore lead to waves with heightened dispersion in firm quality, higher information asymmetry surrounding firm value and hence higher average initial return during 'hot' IPO markets.

\section{Early aftermarket trading}

In addition to information asymmetry surrounding IPO value between market participants in the primary market, the literature attributes persistent average initial return also to early aftermarket trading activity (see, for example, Chen, Hung and Wu, 2002; Ellis 2006; Agarwal, 2003). Persistent deliberate underpricing in the primary market creates excess demand in the aftermarket when IPO shares become available for trading. This excess demand will push up prices to a new equilibrium and allows selling shareholders in the secondary market to earn significant returns. We refer to the difference between the market price and the 'fair' offer price as mispricing in the aftermarket. Five variables explain mispricing in the early aftermarket.

The number of shares traded on the first day as percentage of shares offered serves as a proxy variable to take account of the trading volume and excess demand of IPOs in the aftermarket. Existing research reports of a positive association between initial return and trading volume in the 
aftermarket (Aggarwal, 2000, 2003; Chahine, 2007; Ellis, Michaely and O'Hara, 2000, 2002; Ellis, 2006).

Two dummy variables capture the aftermarket demand in IPO shares via the price revision from the initial filing range to the offer price (Hanley, 1993) as an indicator of the likelihood of flipping taking place. We code dummy variables equal to one if the offer price is above or below the initial filing price range. More investors buy or sell shares if shares are offered above or below the initial filing price range. Ellis (2006) observes a significant association between these two dummy variables and trading volume.

Equity retention by pre-IPO owners immediately after flotation serves as a proxy measure for ownership concentration. Average initial return is attributable to a signalling effect by firm insiders to outside investors. Chen, Hung and Wu (2002) report a negative association between ownership concentration and aftermarket mispricing.

Underwriter reputation captures distribution networks and institutional contacts. Ellis (2006) reports greater trading volumes for more reputable underwriters. The author argues that higher quality underwriters have a greater ability to generate interest among investors through more established distribution networks and institutional contacts. In addition, more reputable underwriters have a higher reputation capital at stake and hence are more likely to provide price support in the aftermarket.

Offer size captures the risk of an IPO. Investors perceive smaller IPOs as riskier compared to larger new issues of more established companies. Beatty and Ritter (1986), Ritter (1987), and Carter (1992) observe a negative association between offer size and initial return.

\section{Data and methods}

\subsection{Data}

Our initial source is the New Issues database in Thomson One Banker, from which we obtain 3,131 observations with all relevant variables on U.S. IPOs from January 1980 to December 2012. This sample excludes closed-end funds, American Depository Receipts (ADRs), Master Limited Partnerships (MLPs), Real Estate Investment Trusts, unit offers, all new issues with an offer price below $\$ 5$, and IPOs with an offer price greater than $\$ 1000$. Data items we obtain from Thomson One include issuing firm attributes, deal characteristics, and aftermarket trading data. We use financial statement data from Compustat and trading data for each IPO firm from the Centre for Research in Security Prices (CRSP) to complement our variables list and fill in missing price observations in Thomson One. ${ }^{9}$ Jay Ritter's web site provides the rankings on underwriter

\footnotetext{
${ }^{9}$ Key financial statement data leading up to flotation was missing for many firms in Thomson One and Compustat.
} 
reputation and aggregate data on the new equity issues market. The Federal Reserve Bank of St. Louis is our last data source which supplies data on private non-residential fixed investment across the sample period to identify firms' demand for private capital. Our sample excludes observations with missing values on the variables of interest.

Figure 2 graphs number of IPOs against average initial return for our sample. Overall, the cyclicity is representative of the data reported on Jay Ritter's web site.

\section{Figure 2: Average initial return and number of U.S. IPOs by quarterly intervals, 1980-2012}

Average initial return per quarter is the equally-weighted mean of the percentage change from the offer price in the premarket to the aftermarket price.

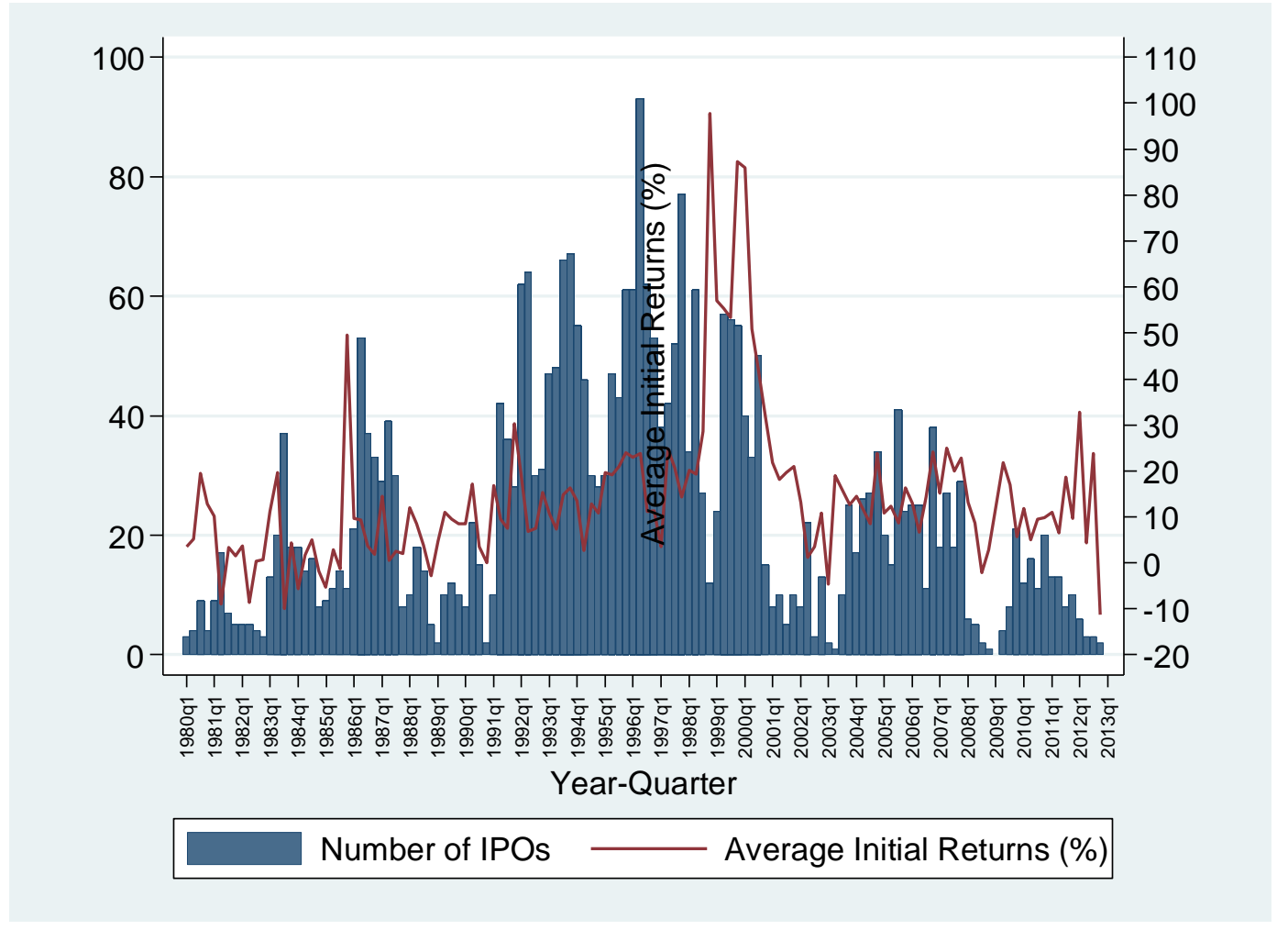

Table 1 shows the sample distribution of IPOs across our industry sector classification at the twodigit SIC level. Both the number of IPOs and average initial return differ across industry sectors. There is no perfect correlation between the number of IPOs and average initial return. 'Computers' has the highest concentration in terms of the number of offers as well as the highest average initial return. 'Utilities' has the lowest concentration of new issues, while 'Oil and Gas' record the lowest average initial return across the sectors. 
Table 1: IPO sample distribution across industry sectors

Our sample consists of 3,131 offers between 1980 and 2012, classified into Standard Industrial Classification (SIC) sectors corresponding to Koop and Li's (2001) industry classification.

\begin{tabular}{lccc}
\hline Industry & Two-digit SIC codes & $\begin{array}{c}\text { Number } \\
\text { of IPOs }\end{array}$ & $\begin{array}{c}\text { Average Initial } \\
\text { return (\%) }\end{array}$ \\
\hline Chemical Product & 28 & 199 & 9.436 \\
Communications & 48 & 115 & 16.050 \\
Computers & 35,73 & 754 & 34.939 \\
Electronic Equipment & 36 & 239 & 27.858 \\
Financial Services & $60-65,67$ & 238 & 14.844 \\
Health & 80 & 89 & 9.466 \\
Manufacturing & $30-34$ & 115 & 15.945 \\
Oil and Gas & 13,29 & 97 & 5.500 \\
Retail & $53,54,56,57,59$ & 209 & 11.053 \\
Scientific Instruments & 38 & 199 & 16.345 \\
Transportation & $37,39,40-42,44,45$ & 157 & 11.978 \\
Utilities & 49 & 56 & 9.188 \\
All Others & $1,2,7,10,12,14, \ldots$ & 664 & 12.872 \\
\hline Total & & 3131 & 19.085 \\
\hline
\end{tabular}

\subsection{Definition and measurement of variables}

Table 2 lists the variables, their definitions and measurements as well as the corresponding data sources. Offer price per share is the primary variable of interest We employ several pricing factors as the primary value driver for equity. Earnings before interest, tax, depreciation and amortization is the proxy measure for a more long-term stream of operating cash flow because the latter is subject to higher annual volatility. Industry dummy variables reflect Koop and Li's (2001) 12 industry sectors based on Fama and French's (1997) two-digit classification. These industry sector dummy variables take account of differences in the cost of capital, business risk, future earnings potential, and growth opportunities of IPO firms across industries. A dummy variable captures negative earnings in the accounting period before going public as a proxy for future growth opportunities rather than current profitability. We also include historic R\&D spending as an indicator for future growth opportunities. Book value of assets in the most recent twelve-month accounting period before going public acts as the lower bound for IPO value. Financial leverage is the last pricing factor and measures financial distress of firms.

We use various factors to explain variations in deliberate premarket underpricing. Issuing firm attributes that take account of ex ante uncertainty include sales in the accounting period before flotation and firm age. In addition to firm attributes, we include several deal characteristics as proxy measures to explain deliberate premarket underpricing. They include equity retained by pre-IPO shareholders after the issue, proceeds raised at the disposal of the issuing firm, the 
commitment of pre-IPO owners not to sell additional shares immediately in the aftermath of the issue, underwriting fees, and logarithm of one plus the number of uses of proceeds disclosed in the

\section{Table 2: Variable definitions, measurements and data sources}

This table presents the definitions of the dependent and independent variables used in the SFA model and the later model for aftermarket mispricing. For the SFA model, offer price per share is the variable of primary interest. Pricing factors and underpricing factors are the independent variables. The pricing factors represent the primary value drivers of equity. The underpricing factors explain the deliberate premarket underpricing and these include proxy variables relating to issuing firm attributes, deal (offer) characteristics, third-party certification, new issues market conditions, and private firms' demand for capital. For the aftermarket mispricing model, the dependent variable is aftermarket mispricing retrieved after estimation of the SFA model. This aftermarket mispricing component is explained by a number of variables proxying trading volume, likelihood of flipping, ownership concentration, underwriter reputation and offer risk. Data sources include Thomson One Banker, Compustat, Centre for Research in Security Prices (CRSP), Jay Ritter's web site [http://bear.warrington.ufl.edu/ritter/ipodata.htm], Fama and French's (1997) industry sector classification, and the Federal Reserve Bank of St. Louis.

\begin{tabular}{|c|c|c|}
\hline & Variables used in the Stochastic Frontier Model & Source \\
\hline \multicolumn{3}{|c|}{ Dependent Variable } \\
\hline Offer price & Offer price per share in US\$. & Thomson \\
\hline \multicolumn{3}{|c|}{ Pricing Factors } \\
\hline EBITDA & $\begin{array}{l}\text { Earnings before interest, tax, depreciation and amortization (EBITDA) in US\$ million in } \\
\text { the accounting period before IPO. }\end{array}$ & Compustat \\
\hline $\begin{array}{l}\text { Industry } \\
\text { dummies }\end{array}$ & $\begin{array}{l}\text { Industry sector dummy variables as proxy variables for differences in the cost of capital } \\
\text { and earnings potential between industry sectors, based on Fama and French's (1997) } \\
\text { industry classification at the two-digit level to discriminate between IPOs coming from } \\
12 \text { different industry sectors in line with Koop and Li (2001). }\end{array}$ & $\begin{array}{l}\text { Fama and French } \\
\text { (1997), Koop and Li } \\
(2001)\end{array}$ \\
\hline $\begin{array}{l}\text { Negative net } \\
\text { income }\end{array}$ & $\begin{array}{l}\text { Dummy variable coded one if the firm has a negative net income in the accounting } \\
\text { period before going public, else coded zero. }\end{array}$ & Compustat \\
\hline $\begin{array}{l}\text { Capital } \\
\text { expenditure }\end{array}$ & R\&D investment in US\$ million in the accounting period before IPO. & Compustat \\
\hline Assets & Total assets in US $\$$ million in the accounting period before IPO. & Thomson, Compustat \\
\hline Leverage & $\begin{array}{l}\text { Long-term debt scaled by book values of total assets in the accounting period before } \\
\text { IPO. }\end{array}$ & Compustat \\
\hline \multicolumn{3}{|c|}{ Underpricing Factors } \\
\hline \multicolumn{2}{|c|}{ Issuing firm attributes } & \\
\hline Sales & Sales in US\$ million in the accounting period before IPO. & Compustat \\
\hline Firm Age & Number of years between the date the company was founded and the IPO date. & Compustat \\
\hline \multicolumn{2}{|c|}{ Deal (offer) characteristics } & \\
\hline $\begin{array}{l}\text { Equity } \\
\text { retained }\end{array}$ & $\begin{array}{l}\text { Leland and Pyle's (1977) signal of equity retained: } \hat{\alpha}=R E T+\ln (1-R E T) \text {, where } R E T \\
\text { is the proportion of equity retained by pre-IPO shareholders in the post-IPO firm. }\end{array}$ & Thomson \\
\hline Proceeds & $\begin{array}{l}\text { Proceeds in US\$ million at the disposal of the issuing firm, measured by the number of } \\
\text { primary shares times the offer price per share in US\$. }\end{array}$ & Thomson \\
\hline Lock-in & $\begin{array}{l}\text { Dummy variable coded one if the flotation prospectus discloses the presence of a 'lock- } \\
\text { in' agreement, else coded zero. }\end{array}$ & Thomson \\
\hline Fees & Underwriting fees in US\$ million. & Thomson \\
\hline $\begin{array}{l}\ln (1+ \\
\text { number of } \\
\text { uses of } \\
\text { proceeds) }\end{array}$ & $\begin{array}{l}\text { Logarithm of one plus the number of uses of IPO proceeds disclosed in the flotation } \\
\text { prospectus. }\end{array}$ & Thomson \\
\hline \multicolumn{2}{|c|}{ Third-party certification } & \\
\hline Reputation & $\begin{array}{l}\text { Underwriter reputation based on tombstone rankings used in Carter and Manaster } \\
\text { (1990), Carter and Dark (1993) and Carter, Dark and Singh (1998). Updated rankings } \\
\text { are available from Jay Ritter's web page. }\end{array}$ & $\begin{array}{l}\text { Jay Ritter's IPO } \\
\text { website }\end{array}$ \\
\hline
\end{tabular}




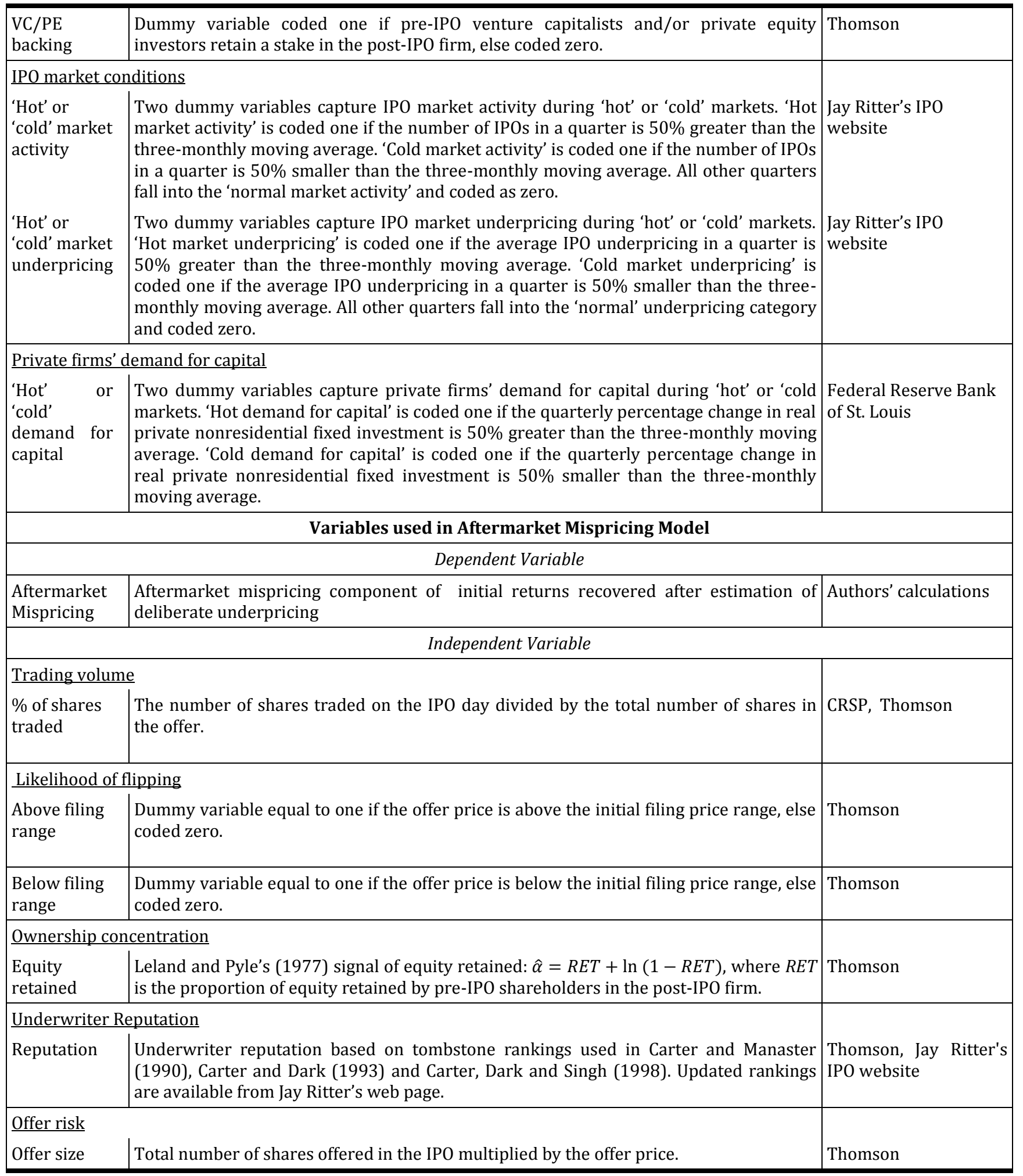

flotation prospectus. Furthermore, we use third-party certification to explain deliberate premarket underpricing. Underwriter reputation rankings are available from Jay Ritter's web site. We use the average rank of underwriters for those IPO deals that have more than one underwriter. A dummy variable captures IPOs with private equity backing and/or venture capital backing. To account for IPO market conditions, we use Yung, Çolak and Wei's (2008) approach to classify aggregate IPO 
number and aggregate average initial return into 'hot', 'cold' and 'normal' new issues market activity. Finally, we use the same classification approach for private firms' demand for capital.

We also employ several proxy variables to explain aftermarket mispricing. Trading volume captures the demand in shares, defined as the number of shares traded on the first day as a percentage of shares offered. To capture the likelihood of flipping shares in the early aftermarket, we create two dummy variables indicating if the offer price is below or above the initial filing price range. Equity retained by pre-IPO owners after flotation measures ownership concentration. Underwriter ranking measures the reputation capital at stake. More reputable underwriters are more likely to provide price support in the aftermarket. We also control for offer size to capture the riskiness of an IPO. Smaller offers are normally riskier and hence have higher levels of initial return.

Table 3 presents summary statistics for the sample of 3,131 IPOs between January 1980 and December 2012. The small difference between the mean offer price and the median offer price suggests that the distribution of the dependent variable is close to symmetric. Although the average EBITDA is positive, the range between the minimum and maximum is large. Interestingly, no fewer than 695 companies in our sample disclose negative earnings in the accounting period leading up to flotation. Obtaining a stock market listing is therefore not exclusively reserved for profitable companies. For example, General Motors has the single largest loss amounting to $\$ 4,431$ million. Sample firms have an average $R \& D$ investment of $\$ 21.3$ million in the accounting period before flotation. The distribution of capital expenditure is positively skewed with a large range between the minimum and maximum amount spent. The average book value of total assets for the sample firms is $\$ 479$ million, ranging between a minimum of $\$ 181,000$ and a maximum of $\$ 217,380$ million. Some sample firms have no debt in their capital structure, whereas the maximum financial leverage is close to one at the time of flotation.

Average sales amount to $\$ 298$ million. The distribution of sales is positively skewed and has a standard deviation of $\$ 2,177$ million. On average, IPO firms are 18 years old. Pre-IPO shareholders retain about $68 \%$ of the shares at flotation. Some of the original owners sell their entire stake at flotation, whereas others retain a significant proportion of their shares in the post-IPO firm. The average IPO proceeds at the disposal of the firm is $\$ 92.9$ million. The majority of IPO firms in our sample have a lock-in agreement in which original shareholders declare not to sell any shares immediately following the flotation. On average, underwriting fees amount to \$1.1 million. Firms disclose an average of two uses of proceeds in the flotation prospectus. Average underwriter reputation using Carter and Manaster's (1980) methodology based on tombstone rankings of investment banks is 7.6 . Only about $12 \%$ of firms in our sample have venture capital and/or private equity backing. 
The majority of our sample firms have their IPO during normal new issues market activity, average aggregate levels of initial return, and average demand for private capital. The average offer price is neither above nor below the initial filing price range. On average, the amount of the offer size in our sample is $\$ 108.1$ million.

Table 3: Summary statistics

This table presents summary statistics for 3,131 IPOs between January 1980 and December 2012. See Table 2 for definitions of the variables presented here.

\begin{tabular}{lccccc}
\hline & Mean & Median & Std. Dev. & Min. & Max. \\
\hline Offer Price (\$) & 13.508 & 13 & 5.814 & 5.100 & 100 \\
EBITDA (\$million) & 37.972 & 4.961 & 362.330 & -4431.000 & 17121 \\
Negative net income & 0.222 & 0 & 0.416 & 0 & 1 \\
Capital Expenditure (\$million) & 21.321 & 2.148 & 153.225 & 0.004 & 5431 \\
Assets (\$million) & 479.449 & 37.866 & 4906.155 & 0.181 & 217380 \\
Leverage & 0.265 & 0.196 & 0.247 & 0 & 0.999 \\
Sales (\$million) & 298.303 & 45.074 & 2176.969 & 0.007 & 104589 \\
Firm Age (years) & 18.321 & 9 & 22.921 & 1 & 165 \\
Equity Retained & 0.684 & 0.711 & 0.166 & 0 & 0.992 \\
Proceeds (\$million) & 92.857 & 39 & 356.253 & 2.100 & 16006.877 \\
Lock-in Dummy & 0.674 & 1 & 0.469 & 0 & 1 \\
Fees (\$million) & 1.118 & 0.590 & 1.920 & 0.005 & 35.215 \\
Number of Uses of Proceeds & 2.017 & 1 & 1.761 & 0 & 11 \\
Reputation & 7.607 & 8.001 & 1.769 & 0 & 9.001 \\
VC/PE Backing & 0.118 & 0 & 0.323 & 0 & 1 \\
Hot Market Activity & 0.042 & 0 & 0.200 & 0 & 1 \\
Cold Market Activity & 0.019 & 0 & 0.138 & 0 & 1 \\
Hot Market Underpricing & 0.075 & 0 & 0.264 & 0 & 1 \\
Cold Market Underpricing & 0.086 & 0 & 0.281 & 0 & 1 \\
Hot Demand for Private Capital & 0.259 & 0 & 0.438 & 0 & 1 \\
Cold Demand for Private Capital & 0.257 & 0 & 0.437 & 0 & 1 \\
\% Shares Traded & 72.525 & 59.708 & 55.516 & 0 & 516.576 \\
Above Filing Range & 0.167 & 0 & 0.373 & 0 & 1 \\
Below Filing Range & 0.168 & 0 & 0.374 & 0 & 1 \\
Offer Size (\$million) & 108.099 & 41.600 & 564.617 & 2.300 & 23900 \\
\hline & & & & & \\
\hline
\end{tabular}

\subsection{Estimating "fair" offer prices: Stochastic Frontier Analysis}

We use Stochastic Frontier Analysis (SFA) to estimate the fair offer price for each of the IPOs. SFA, a parametric technique originally proposed independently by Aigner, Lovell and Schmidt (1977) and Meeusen and Van Den Broeck (1977), allows us to estimate the frontier of (unobserved) maximum "fair" offer prices that would prevail in the absence of information asymmetry. We write the IPO price stochastic frontier as:

$$
O P=f(X \beta)+v-u
$$

where $\mathrm{OP}$ is the observed offer price, $\mathrm{X}$ is a vector of observed characteristics (pricing factors) that affect the firm's offer price and $\beta$ is a vector of parameters to be estimated. The term $f(X \beta)$ 
captures the deterministic part of the relationship between offer price and the pricing factors. Random factors can cause deviations of the actual offer price from the deterministic frontier and is captured by the term $v$ which is assumed to have a normal distribution, hence producing the stochastic frontier, which is the offer pricing level that the firm seeks to attain. If actual offer prices are systematically below the optimal frontier offer price offer, due to, for example information asymmetry, then this is reflected by the term $u$, which is commonly assumed to have a one-sided distribution. ${ }^{10}$ This term $u$ captures the degree of deliberate premarket underpricing. As a parametric estimation method, SFA can separate out the two-sided noise from the one-sided component in the estimation of the IPO frontier, hence allowing us to estimate deliberate premarket underpricing.

An important development in the SFA literature, but less frequently explored in empirical applications, is the modelling of exogenous factors that affect the distance from the frontier. Given a fairly large literature focused on explaining the drivers of IPO underpricing, we incorporate these underpricing factors into the frontier model and explicitly model the conditional variance or heteroscedasticity of the one-sided error term when fitting the IPO offer price frontier (see Kumbhakar and Lovell, 2000). Given the normal-half-normal distribution assumed on the combined error component, the one-sided error variance is modelled simultaneously with the frontier as $u \sim N^{+}\left(0, \sigma_{u_{i}}^{2}\right)$ and $v \sim N\left(0, \sigma_{v}^{2}\right):$

$$
\sigma_{u_{i}}^{2}=f\left(Z_{i} \gamma\right)
$$

where $Z$ is a vector capturing the various underpricing factors, and $\gamma$ is a vector of parameters to be estimated. In the case where the variances of both error components are constant, equation (1) is estimated through maximum likelihood techniques on the following log-likelihood function:

$$
\ln L=\sum_{i=1}^{N} \frac{1}{2} \ln \left(\frac{2}{\pi}\right)-\ln \sigma_{S}+\ln \Phi\left(\frac{-\varepsilon_{i} \lambda}{\sigma_{S}}\right)-\frac{\varepsilon_{i}^{2}}{2 \sigma_{S}^{2}}
$$

where $\sigma_{s}=\sqrt{\left(\sigma_{u}^{2}+\sigma_{v}^{2}\right)} ; \quad \lambda=\frac{\sigma_{u}}{\sigma_{v}} ; \quad \varepsilon_{i}=y_{i}-X_{i} \beta ; \quad \Phi($.$) is the cumulative distribution function$ of the standard normal distribution. If either or both variances are non-constant, as in equation (2), $\sigma_{u}$ or/and $\sigma_{v}$ will be replaced with $\sigma_{i}^{2}=\exp \left(Z_{i} \gamma\right)$ in the above log-likelihood function. Once the frontier is estimated, we can construct measures of the distance of observed offer price from fair offer price as:

\footnotetext{
${ }^{10}$ While the half-normal distribution is most commonly used, alternatives such as the exponential, gamma and truncated normal distributions have also been used for the simple stochastic frontier model.
} 


$$
E\left(u_{i} \mid \varepsilon_{i}\right)=\mu_{*_{i}}+\sigma_{*}\left\{\frac{\phi\left(-\mu_{*_{i}} / \sigma_{*}\right)}{\Phi\left(\mu_{*_{i}} / \sigma_{*}\right)}\right\}
$$

We can then construct the measure of underpricing (UP), i.e. the proportionate distance of actual offer price from the theoretical frontier offer price:

$$
U P_{i}=E\left\{\frac{1-\Phi\left(\sigma_{*}-\frac{\mu_{*_{i}}}{\sigma_{*}}\right)}{1-\Phi\left(-\frac{\mu_{*_{i}}}{\sigma_{*}}\right)}\right\} \exp \left\{-\mu_{*_{i}}+\frac{1}{2} \sigma_{*}^{2}\right\}
$$

where $\mu_{* i}=\frac{\varepsilon_{i} \sigma_{u}^{2}}{\sigma_{S}^{2}} ; \quad \sigma_{*}=\frac{\sigma_{u} \sigma_{v}}{\sigma_{S}} ; \phi($.$) is the density for the standard normal distribution and$ other terms are as defined earlier.

In addition to estimating the stochastic frontier model in equation (1) and simultaneously modelling the determinants of underpricing in equation (2) in one step, we also calculate and report an R-squared measure developed recently by Liu and Meyers (2009) that summarises the overall explanatory power of the determinants of inefficiency (underpricing in our case). Liu and Meyers (2009) propose that this measure $\left(R_{Z}^{2}\right)$ is calculated as follows:

$$
R_{Z}^{2}=\frac{\sum_{i=1}^{n}\left[\hat{E}\left(u_{i} \mid Z_{i}\right)-\frac{1}{n} \sum_{i=1}^{n} \hat{E}\left(u_{i} \mid Z_{i}\right)\right]^{2}}{\sum_{i=1}^{n}\left[\hat{E}\left(u_{i} \mid Z_{i}\right)-\frac{1}{n} \sum_{i=1}^{n} \hat{E}\left(u_{i} \mid Z_{i}\right)\right]^{2}+\sum_{i=1}^{n} \hat{V}\left(u_{i} \mid Z_{i}\right)}
$$

where $\hat{E}$ and $\hat{V}$ are sample estimates of the mean and variance of the deliberate underpricing component $u_{i}$ conditional on its determinants $Z_{i}$. These two components are constructed as follows:

$$
\begin{aligned}
& \hat{E}\left(u_{i} \mid Z_{i}\right)=\sigma_{i}\left(R_{1}+R_{2}\right) \\
& \hat{V}\left(u_{i} \mid Z_{i}\right)=\sigma_{u}^{2}\left(1+R_{3}\right)
\end{aligned}
$$

where $R_{1}=\frac{\mu_{i}}{\sigma_{i}}, R_{2}=\phi\left(R_{1}\right)\left[\Phi\left(R_{1}\right)\right]^{-1}, R_{3}=-R_{2}^{2}-R_{1} R_{2}$ 
Hence, once we have obtained estimates $\hat{\mu}_{i}$ and $\hat{\sigma}_{i}$, equation (6) can be calculated and interpreted as the fraction of the sample variation in $u$ that can be explained by $Z$, similar to the goodness of fit measure from the traditional R-squared in an OLS regression,

\section{Findings}

\section{1. 'Pricing factors' to estimate the maximum achievable offer price}

We use an extended set of pricing factors to estimate the maximum (fair) achievable offer price compared to the ones used in previous studies. This approach allows us to provide more precise estimates of fair offer prices and hence better estimates of deliberate premarket underpricing as well as aftermarket mispricing. Table 4, Panel A, presents the frontier parameter estimates, which are corrected for heteroscedasticity in the one-sided error term. The majority of the pricing factors are statistically significant in explaining the maximum achievable offer price across our models with the exception of some industry dummy variables.

The coefficients on earnings before interest, tax, depreciation and amortization (EBITDA) are positive and statistically significant across all models. Our results therefore corroborate earlier evidence on the importance of EBITDA as a value driver, such as, for example, Teoh, Welch and Wong (1998), Koop and Li (2001), Chen, Heng and Wu (2002), and Aggarwal, Bhagat and Rangan (2009).

We retain all industry dummy variables across our models to account for differences in the cost of capital and business risk in line with Koop and Li's (2001) sector classification. Our findings show that sectors such as computers, communications, retail and financial services have, on average, higher offer prices, whereas manufacturing has, on average, lower offer prices compared to the base sectors. Whether offer price in the remaining sectors are higher or lower on average compared to the base category is not clear-cut and depends on model complexity.

We use a binary indicator of negative net income and the amount of capital expenditure during the accounting period leading up to an IPO to proxy future earnings potential as well as growth opportunities. Firms with a negative net income in the year prior to IPO have, on average, lower valuations. We therefore conclude that this dummy variable is more likely to capture the impact of current profitability rather than future growth opportunities as Aggarwal, Bhagat and Rangan (2009) advocate. Higher capital expenditure is a significant positive value driver. Our findings corroborate earlier claims that historic R\&D spending is an important indicator for future growth opportunities as reported in studies such as, for example, Aggarwal, Bhagat and Rangan (2009), Hertzel, Huson and Parrino (2012), and Deeds, Decarolis and Coombs (1997).

Firms with a higher asset base on average, have higher valuations. Our findings are intuitive in that the book value of assets represents a lower bound for IPO value. The studies of Hunt-McCool, 
Koh and Francis (1996) and Koop and Li (2001), and Peng and Wang (2007) provide further evidence in support of our findings. Therefore, we do not support Chen, Hung and Wu's (2002) claim that potential growth and hence IPO value is lower for firms with a greater asset base at the time of a flotation.

Issuers with higher levels of financial leverage at the IPO have, on average, lower offer prices because of greater risk and distress costs. Lower valuations reflect an increased probability of firms going into bankruptcy as a result of greater financial risk. Our findings corroborate those reported in Koop and Li (2001) and Peng and Wang (2007).

\subsection{Factors explaining deliberate premarket underpricing}

We explain deliberate premarket underpricing as a result of information asymmetries between new issues market participants at various stages leading up to an IPO, while holding the 'pricing factors' constant. Panel B presents six models in which we introduce our proxy variables block by block to capture information asymmetries at various stages of an IPO process. Across all these models, we report the R-squared measure for the explanatory power of the determinants of underpricing $\left(\mathrm{R}_{\mathrm{Z}}{ }^{2}\right)$ as captured in equation (6). The R-squared is reasonably high across models (2) to (6), converging at around 58\%, indicating that the variables we have used as determinants of underpricing can explain quite a large fraction of the variation in our estimates of underpricing. ${ }^{11}$ Model 1 explains underpricing as a function of ex ante uncertainty surrounding firm value (Rock, 1986; Beatty and Ritter, 1986). Ex ante uncertainty captures how established firms are before taking into account any IPO deal characteristics. Sales in the accounting period before going public and firm age, measured in years between the date of incorporation and the IPO date, are the two proxy variables to capture ex ante uncertainty. Both the coefficient for sales and firm age are inconsistent with the ex ante uncertainty argument. The coefficient for sales is statistically insignificant, while firm age has a positive relationship with underpricing. We conclude that the amount of sales is perhaps less likely to capture the level of ex ante uncertainty as reported elsewhere in the IPO literature that relies on the aggregate initial return rather than the deliberate premarket underpricing. Hunt-McCool, Koh and Francis (1996), Koop and Li (2001) and Aggarwal, Bhagat and Rangan (2009) report a positive association between sales and IPO value. Firm age also does not appear to capture the ex ante uncertainty with respect to deliberate premarket underpricing as reported elsewhere in the literature. Hunt-McCool, Koh and Francis (1996) show a positive correlation between firm age and IPO value.

Model 2 augments Model 1 with variables on deal characteristics for each IPO. We only find partial support for a joint signalling effect of equity retained by pre-IPO owners in the post-IPO firm

\footnotetext{
11 To the best of our knowledge, there is no study that reports this specific measure of R-squared in the context of a one-stage stochastic frontier model investigating the determinants of underpricing.
} 
and the proceeds at the disposal of the issuer (Downes and Heinkel, 1982; Ritter, 1984b; Kim and Weisback, 2008). While the coefficient for proceeds has the correct sign and is statistically significant, the coefficient for equity retained is statistically insignificant. Our findings therefore present evidence that equity retained is an unlikely signalling mechanism to convey firm value to outside investors. Previous studies which have used related SFA frameworks to examine the relationship between equity retained and estimated offer value report a positive association (HuntMcCool, Koh and Francis, 1996), no association (Chen, Hung and $\mathrm{Wu}, 2002$ ), or omit the variable altogether (Koop and Li, 2001). Hunt-McCool, Koh and Francis (1996) also report a positive association between proceeds and offer price. Peng and Wang (2007) report a negative relationship between proceeds and pricing inefficiency. Other studies, including those of Koop and Li (2001) and Chen, Hung and $\mathrm{Wu}$ (2002) do not include proceeds as a joint signalling variable.

The impact of lock-in agreements on underpricing in a SFA framework awaits investigation. Our findings show that the presence of lock-in agreements by pre-IPO owners increases the level of uncertainty and hence underpricing. The supply of tradable shares can increase at the time when the lock-in period expires. Our evidence therefore corroborates the findings of existing studies such as, for example, Bradley, Jordan, Ha-Chin and Roten (2001), and Field and Hanka (2001).

The coefficient for underwriter fees is positive and statistically significant. We can conclude that fees will be higher for those IPOs about which relatively little public information is available and hence these exhibit higher levels of underpricing. Our findings are in line and hence corroborate the evidence reported in Hunt-McCool, Koh and Francis (1996). They report a negative association between underwriter compensation and estimated offer price. In contrast, Koop and Li (2001) report a positive relationship between fees and offer price. However, their result could reflect less competition in the corresponding underwriting market. Neither Hunt-McCool, Koh and Francis (1996), nor Koop and Li (2001) control simultaneously for underwriter reputation in their analysis.

We find a positive relationship between the logarithm of the number of uses of proceeds and underpricing. A greater number of uses of proceeds increases the ex ante uncertainty and hence also the underpricing. The number of uses of proceeds has not attracted any attention in the existing literature using SFA. Our findings are consistent with those of Beatty and Ritter (1986). They do not distinguish between deliberate premarket underpricing and aftermarket mispricing. Since the number of uses of proceeds is endogenous we simultaneously control for other deal characteristics.

Adding the deal characteristics in Model 2 and subsequent models brings about significant positive coefficients for sales as well as negative coefficients for firm age. A positive coefficient for sales contradicts the ex-ante uncertainty argument. One possible explanation of this unexpected result is that higher levels of sales may make future growth opportunities more difficult and hence 
uncertain. Older firms now have a reduced underpricing which is consistent with the ex ante uncertainty argument.

Model 3 augments Model 2 with underwriter reputation and private-equity and/or venture capital backing as proxy variables to capture third-party certification, to reduce ex ante uncertainty and hence underpricing. On the one hand, our findings cannot detect any relationship between underwriter reputation and underpricing. More reputable underwriters can therefore neither take advantage of a principal-agent relationship (Baron, 1982), nor do they play a third-party certification role (Carter and Manaster, 1990). We therefore conclude that underwriter reputation does not impact on the level of deliberate premarket underpricing as reported elsewhere in the literature that employs initial return without any segregation. On the other hand, private equity backing and/or venture capital backing adds to the explanatory power of underpricing. The coefficient for this third-party certification dummy variable is positive and statistically significant. Our study is the first to provide such evidence in a SFA framework. Our findings therefore support Liu and Ritter's (2011) claim that venture capital backed IPOs have higher underpricing as a result of attracting more coverage from analysts.

In the remaining three models (Model 4, Model 5, and Model 6), we introduce proxy variables that capture new equity issues market conditions and private firms' demand for capital at the time of an IPO. Model 4 includes 'hot' and 'cold' dummy variables to capture aggregate number of new issues. In Model 5, 'hot' and 'cold' dummy variables take account of aggregate average initial return. Neither the aggregate number of issues, nor the aggregate levels of initial return explain deliberate premarket underpricing. This result is somewhat surprising since the literature reports cyclicity in both the number of IPOs and the level of average initial return. Our study is the first to analyse the impact of these two factors on the level of deliberate premarket underpricing. We conclude from our analysis that premarket underpricing is independent of IPO market conditions at the time of a particular new issue.

In Model 6, we use the change in real private nonresidential fixed investment as proxy for private firms' demand for capital. The impact of this proxy variable has not attracted any attention in existing studies using a SFA framework. Our findings indicate lower average underpricing during periods of 'hot' demand for private firms' capital. This result is similar to the evidence provided in Yung, Çolak and Wei (2008). However, they do not use the more refined measure of deliberate premarket underpricing. Our findings also show that 'cold' periods for private firms' demand for capital have lower average underpricing. This evidence is somewhat surprising and would suggest that any exogenous shock leads to a lower average underpricing and deserves future investigation in other stock markets. 


\section{Table 4: Estimates of stochastic pricing frontiers and the level of deliberate premarket underpricing}

All six models use the same pricing factors (Panel A). Panel B shows the factors that explain variations in deliberate underpricing. Panel C reports the initial return decomposed into deliberate underpricing and early aftermarket mispricing. Model 1 is the basic model and explains deliberate underpricing as a function of ex ante uncertainty surrounding firm value between new issues market participants. Model 2 augments Model 1 with variables that capture deal characteristics. Model 3 augments the previous models with third-party certification variables. Model 4 augments previous models with 'hot' and 'cold' dummy variables to capture the aggregate number of new issues at the time of a particular IPO. Model 5 replaces the aggregate number of new issues with the aggregate initial return at the time of a particular IPO. Model 6 replaces the aggregate initial return with the demand for private capital.

\section{(1)}

(2)
(4)

(6)

\section{Panel A: Pricing Factors}

Ln (EBIDTA)

Negative EBIDTA

Ln (Capital Expenditure)

Ln (Total Assets)

Ln (Leverage)

Oil and Gas

Manufacturing

Computers

Electronic Equipment

Transportation

Scientific Instruments

Communications

Utilities

Retail

Financial Services

Health

Chemical Products

Constant

$\ln \sigma_{v}^{2}$

Constant

\begin{tabular}{|c|c|c|c|c|c|}
\hline $0.027^{* * *}$ & $0.025^{* * *}$ & $0.023^{* * *}$ & $0.023^{* * *}$ & $0.023^{* * *}$ & $0.023^{* * *}$ \\
\hline$(0.006)$ & $(0.007)$ & (0.007) & $(0.007)$ & $(0.007)$ & (0.007) \\
\hline$-0.128^{* * *}$ & $-0.184^{* * *}$ & $-0.180^{* * *}$ & $-0.179 * * *$ & $-0.178^{* * *}$ & $-0.179 * * *$ \\
\hline$(0.049)$ & $(0.050)$ & $(0.051)$ & $(0.051)$ & $(0.051)$ & $(0.051)$ \\
\hline $0.046^{* * *}$ & $0.032^{* * *}$ & $0.031^{* * *}$ & $0.031^{* * *}$ & $0.031^{* * *}$ & $0.031^{* * *}$ \\
\hline$(0.005)$ & $(0.005)$ & $(0.005)$ & $(0.005)$ & $(0.005)$ & $(0.005)$ \\
\hline $0.064^{* * *}$ & $0.020^{* * *}$ & $0.021^{* * *}$ & $0.022^{* * *}$ & $0.022^{* * *}$ & $0.021^{* * *}$ \\
\hline$(0.007)$ & (0.007) & $(0.008)$ & $(0.008)$ & $(0.008)$ & $(0.007)$ \\
\hline$-0.014^{* * *}$ & $-0.013^{* * *}$ & $-0.012^{* * *}$ & $-0.012^{* * *}$ & $-0.012^{* * *}$ & $-0.012^{* * *}$ \\
\hline$(0.004)$ & $(0.004)$ & $(0.004)$ & $(0.004)$ & $(0.004)$ & $(0.004)$ \\
\hline 0.001 & -0.008 & -0.007 & -0.007 & -0.008 & -0.006 \\
\hline$(0.105)$ & $(0.047)$ & $(0.048)$ & $(0.048)$ & $(0.048)$ & $(0.049)$ \\
\hline-0.034 & $-0.071^{*}$ & $-0.070^{*}$ & -0.069 & $-0.070^{*}$ & $-0.070 *$ \\
\hline$(0.031)$ & $(0.042)$ & $(0.0$ & $(0.0$ & $(0.042)$ & $(0.042)$ \\
\hline $0.229 * * *$ & $0.075^{* * *}$ & $0.079 * * *$ & $0.080^{* * *}$ & $0.079 * * *$ & $0.078^{* * *}$ \\
\hline$(0.038)$ & $(0.024)$ & $(0.024)$ & $(0.024)$ & $(0.024)$ & $(0.024)$ \\
\hline $0.130^{*}$ & -0.002 & -0.002 & -0.001 & -0.004 & -0.006 \\
\hline (0.068) & $(0.034)$ & $(0.034)$ & $(0.034)$ & $(0.034)$ & $(0.034)$ \\
\hline-0.019 & 0.000 & -0.003 & -0.003 & -0.005 & -0.004 \\
\hline (0.027) & $(0.038)$ & $(0.038)$ & $(0.038)$ & $(0.038)$ & $(0.038)$ \\
\hline 0.061 & -0.000 & -0.006 & -0.006 & -0.007 & -0.009 \\
\hline (0.093) & $(0.038)$ & $(0.038)$ & $(0.038)$ & $(0.038)$ & $(0.038)$ \\
\hline 0.095 & $0.115^{* * *}$ & $0.118^{* * *}$ & $0.120^{* * *}$ & $0.117^{* * *}$ & $0.119^{* * *}$ \\
\hline$(0.092)$ & $(0.044)$ & $(0.044)$ & $(0.044)$ & $(0.044)$ & $(0.044)$ \\
\hline-0.003 & -0.011 & -0.014 & -0.012 & -0.015 & -0.017 \\
\hline$(0.042)$ & $(0.061)$ & $(0.063)$ & $(0.063)$ & $(0.063)$ & $(0.062)$ \\
\hline 0.101 & $0.053^{*}$ & $0.055^{*}$ & $0.056^{*}$ & $0.055^{*}$ & $0.054^{*}$ \\
\hline$(0.062)$ & $(0.032)$ & $(0.032)$ & $(0.032)$ & $(0.032)$ & $(0.033)$ \\
\hline $0.165^{* *}$ & $0.058^{*}$ & $0.061^{*}$ & $0.062 *$ & $0.064^{*}$ & $0.061^{*}$ \\
\hline$(0.066)$ & $(0.034)$ & $(0.034)$ & $(0.034)$ & $(0.035)$ & $(0.034)$ \\
\hline 0.028 & -0.085 & -0.086 & -0.082 & -0.086 & -0.080 \\
\hline$(0.151)$ & $(0.056)$ & $(0.057)$ & $(0.058)$ & $(0.057)$ & $(0.057)$ \\
\hline $0.124^{* *}$ & 0.025 & 0.026 & 0.027 & 0.026 & 0.021 \\
\hline$(0.060)$ & $(0.042)$ & $(0.042)$ & $(0.042)$ & $(0.042)$ & $(0.043)$ \\
\hline $2.124^{* * *}$ & $2.498^{* * *}$ & $2.501^{* * *}$ & $2.501^{* * *}$ & $2.502^{* * *}$ & $2.503^{* * *}$ \\
\hline$(0.024)$ & $(0.030)$ & $(0.031)$ & $(0.031)$ & $(0.031)$ & $(0.031)$ \\
\hline $\begin{array}{c}-2.395^{* * *} \\
(0.034)\end{array}$ & $\begin{array}{c}-2.807^{* * *} \\
(0.038)\end{array}$ & $\begin{array}{c}-2.811^{* * *} \\
(0.039)\end{array}$ & $\begin{array}{c}-2.814^{* * *} \\
(0.039)\end{array}$ & $\begin{array}{c}-2.813^{* * *} \\
(0.039)\end{array}$ & $\begin{array}{c}-2.815^{* * *} \\
(0.039)\end{array}$ \\
\hline
\end{tabular}


$\ln \sigma_{u_{i}}^{2}$

Ln (Sales)

Ln (Firm Age)

Equity Retained

Ln (Proceeds)

Lock in Dummy

Ln (Underwriter Fee)

Ln (Number of Uses of

Proceeds)

Underwriter Ranking

VC Backing

Hot Market

Cold Market

Oil and Gas

Manufacturing

Computers

Electronic Equipment

Transportation

Scientific Instruments

Communications

Utilities

Retail

Financial Services

Health

Chemical Products

Constant

\begin{tabular}{|c|c|c|c|c|c|}
\hline-0.023 & $0.264^{* * *}$ & $0.263^{* * *}$ & $0.265^{* * *}$ & $0.264^{* * *}$ & $0.263^{* * *}$ \\
\hline$(0.081)$ & $(0.072)$ & $(0.074)$ & $(0.074)$ & $(0.074)$ & $(0.073)$ \\
\hline $0.259^{*}$ & $-0.125^{*}$ & $-0.124^{*}$ & -0.122 & $-0.124^{*}$ & -0.123 \\
\hline \multirow[t]{19}{*}{$(0.154)$} & $(0.076)$ & $(0.075)$ & $(0.075)$ & $(0.075)$ & $(0.075)$ \\
\hline & 0.124 & 0.071 & 0.078 & 0.08 & 0.118 \\
\hline & $(0.182)$ & (0.183) & $(0.183)$ & $(0.184)$ & (0.183) \\
\hline & $-2.666^{* * *}$ & -2.690 & $-2.680^{* * *}$ & -2.66 & $-2.707^{* * *}$ \\
\hline & $(0.303)$ & $(0.3$ & $(0.312)$ & $(0.3$ & $(0.307)$ \\
\hline & $1.140 * * *$ & 1.168 & $1.169 * * *$ & 1.180 & $1.076^{* * *}$ \\
\hline & $(0.184)$ & $(0.191)$ & $(0.190)$ & $(0.192)$ & $(0.191)$ \\
\hline & $0.480^{*}$ & $0.518^{*}$ & $0.523^{*}$ & $0.504^{*}$ & $0.531^{*}$ \\
\hline & $(0.276)$ & $(0.280)$ & $(0.280)$ & $(0.280)$ & $(0.272)$ \\
\hline & $1.024^{* * *}$ & $1.057^{* * *}$ & $1.043^{* * *}$ & $1.046^{* * *}$ & $1.116^{* * *}$ \\
\hline & (0.179) & (0.183) & $(0.182)$ & (0.183) & $(0.184)$ \\
\hline & & -0.022 & -0.022 & -0.025 & -0.019 \\
\hline & & $(0.040)$ & $(0.040)$ & $(0.040)$ & $(0.040)$ \\
\hline & & $0.489 *$ & $0.480^{*}$ & $0.476^{*}$ & $0.514^{*}$ \\
\hline & & $(0.271)$ & $(0.270)$ & $(0.270)$ & $(0.272)$ \\
\hline & & & -0.430 & 0.278 & $-0.361^{* *}$ \\
\hline & & & $(0.465)$ & $(0.262)$ & $(0.165)$ \\
\hline & & & 0.472 & 0.1 & $-0.333^{* *}$ \\
\hline & & & $(0.463)$ & $(0.2$ & $(0.165)$ \\
\hline 19.441 & -0.175 & -0.148 & -0.165 & -0 & -0.027 \\
\hline 27.892$)$ & $(0.982)$ & & $(0.9$ & & \\
\hline-8.852 & -0.431 & -0 & -0.389 & -0. & -0.397 \\
\hline 274.55 & $(0.54$ & $(0.5$ & $(0.541)$ & $(0.5$ & 45) \\
\hline 28.073 & $0.819^{* * *}$ & 0.80 & $0.814^{* * *}$ & 0.80 & $0.775^{* * *}$ \\
\hline 24.19 & $(0.270)$ & $(0.2$ & $(0.272)$ & $(0.2$ & $(0.271)$ \\
\hline 27.66 & 0.410 & 0.3 & 0.403 & 0.3 & 0.364 \\
\hline 24.192$)$ & $(0.385)$ & $(0$. & (0.389) & $(0.3$ & (0.393) \\
\hline-10.439 & 0.115 & 0.08 & 0.069 & 0.0 & 0.054 \\
\hline 486.217) & $(0.434)$ & $(0.4$ & $(0.430)$ & $(0.4$ & $(0.425)$ \\
\hline 25.509 & 0.439 & 0.332 & 0.345 & 0.328 & 0.303 \\
\hline 224.199) & $(0.395)$ & $(0.404)$ & $(0.407)$ & $(0.406)$ & $(0.407)$ \\
\hline 25.989 & $1.726^{* * *}$ & $1.756^{* * *}$ & $1.777^{* * *}$ & $1.752^{* * *}$ & $1.782 * * *$ \\
\hline 224.197) & $(0.560)$ & $(0.549)$ & $(0.551)$ & $(0.553)$ & $(0.533)$ \\
\hline-6.578 & 0.208 & 0.243 & 0.296 & 0.223 & 0.194 \\
\hline 664.123) & $(0.773)$ & (0.789) & $(0.786)$ & (0.789) & (0.799) \\
\hline 25.009 & -0.055 & -0.0 & -0.011 & -0.026 & -0.029 \\
\hline 24.196$)$ & (0.394) & & (0.398) & $(0.3$ & (0.403) \\
\hline 27.755 & 0.5 & & 0.6 & 0.6 & 0.557 \\
\hline 224.1 & $(0.4$ & & $(0$. & $(0.4)$ & $(0.431)$ \\
\hline 26.618 & 0.007 & 0.0 & 0.094 & 0.0 & 0.133 \\
\hline 24.198$)$ & $(0.633$ & $(0.646)$ & $(0.638)$ & $(0.6$ & $(0.606)$ \\
\hline 28.275 & $1.588^{* * *}$ & $1.558^{* * *}$ & $1.574^{* * *}$ & $1.558^{* * *}$ & $1.551^{* * *}$ \\
\hline 224.192) & $(0.422)$ & $(0.427)$ & $(0.426)$ & $(0.426)$ & $(0.434)$ \\
\hline-31.818 & $3.144^{* * *}$ & $3.321^{* * *}$ & $3.300 * * *$ & $3.251^{* * *}$ & $3.592^{* * *}$ \\
\hline 224.192) & (1.136) & (1.157) & (1.153) & (1.159) & (1.135) \\
\hline-0.0222 & $0.2648^{* * *}$ & $0.2633^{* * *}$ & $0.2655^{* * *}$ & $0.2647^{* * *}$ & $0.2635^{* *}$ \\
\hline
\end{tabular}




\begin{tabular}{lcccccc}
\hline Observations & 3131 & 2437 & 2386 & 2386 & 2386 & 2386 \\
Log-likelihood values & -792.086 & -284.714 & -278.289 & -277.273 & -277.676 & -274.756 \\
$\mathrm{R}_{\mathrm{Z}}{ }^{2}$ & 0.502 & 0.576 & 0.576 & 0.575 & 0.576 & 0.576
\end{tabular}

Panel C: Components of Initial Return

\begin{tabular}{lrrrrrr} 
Initial return (\%) & 19.085 & 19.085 & 19.085 & 19.085 & 19.085 & 19.085 \\
Deliberate Premarket & 7.072 & 13.896 & 14.109 & 14.185 & 14.148 & 14.170 \\
Underpricing (\%) & & & & & & \\
Aftermarket Mispricing (\%) & 9.952 & 3.208 & 3.048 & 2.972 & 3.007 & 2.981 \\
\hline
\end{tabular}

$* \mathrm{p}<0.10, * * \mathrm{p}<0.05, * * * \mathrm{p}<0.01$. Standard errors are in parentheses. $\mathrm{R}_{\mathrm{Z}}^{2}$ is the goodness of fit measure captured in equation (6) for the model of the determinants of underpricing reported in panel B.

\subsection{Disentangling deliberate premarket underpricing and aftermarket mispricing}

We identify deliberate premarket underpricing from the asymmetric component of the variance in our stochastic frontier models. Our estimates of deliberate underpricing in Panel C of Table 4 range between 7.07\% (Model 1) and 14.19\% (Model 4), depending on model complexity. Augmenting Model 1 (the basic model) and introducing deal characteristics, third-party certification, and market conditions block by block results in estimates of deliberate premarket underpricing converging to approximately $14 \%$.

The aftermarket mispricing is the complementary value to deliberate premarket underpricing, with the two components adding up to initial return. As shown in Panel C of Table 4, our estimates of aftermarket mispricing range between 2.97\% (Model 4) and 9.95\% (Model 1), converging to approximately $3 \%$ if we augment our basic model with deal characteristics, third-party certification, and market conditions.

Table 5 presents how much of the variation in our estimates of deliberate premarket underpricing relates to the variation in initial return. As with the frontier exercise, this regression is run on IPOs with positive, negative as well as zero observed initial return ${ }^{12}$, so as not to bias the sample. The coefficient for deliberate premarket underpricing is negative and statistically significant, compared to Hunt-McCool, Koh and Francis (1996) who report a positive and significant coefficient and Chen, Hung, and Wu (2002) who report a positive but insignificant relationship. Both these papers report a very low R-squared ranging between zero and $2 \%$, compared to approximately $3 \%$ in our case. Our results suggest that a portion of initial return can be explained by deliberate premarket underpricing.

\footnotetext{
${ }^{12}$ About $20 \%$ of the sample has zero or negative initial return.
} 


\section{Table 5: OLS regression of IPO initial return on deliberate premarket underpricing}

Estimates of aftermarket mispricing and deliberate premarket underpricing rely on the model definitions used in Table 4 . Initial return is the dependent variable.

\begin{tabular}{|c|c|c|c|c|c|c|}
\hline & (1) & $(2)$ & (3) & (4) & (5) & (6) \\
\hline Deliberate Underpricing & $\begin{array}{c}0.353^{* *} \\
(0.121)\end{array}$ & $\begin{array}{c}-0.559^{* * *} \\
(0.072)\end{array}$ & $\begin{array}{c}-0.575^{* * *} \\
(0.073)\end{array}$ & $\begin{array}{c}-0.581^{* * *} \\
(0.073)\end{array}$ & $\begin{array}{c}-0.579^{* * *} \\
(0.073)\end{array}$ & $\begin{array}{c}-0.579^{* * *} \\
(0.073)\end{array}$ \\
\hline Constant & $\begin{array}{c}16.590^{* * *} \\
(1.174)\end{array}$ & $\begin{array}{c}26.946^{* * *} \\
(1.351)\end{array}$ & $\begin{array}{c}27.374^{* * *} \\
(1.378)\end{array}$ & $\begin{array}{c}27.503^{* * *} \\
(1.380)\end{array}$ & $\begin{array}{c}27.454^{* * *} \\
(1.379) \\
\end{array}$ & $\begin{array}{c}27.460^{* * *} \\
(1.381)\end{array}$ \\
\hline Number of Observations & 2959 & 2290 & 2247 & 2247 & 2247 & 2247 \\
\hline $\mathrm{R}^{2}$ & 0.003 & 0.026 & 0.027 & 0.028 & 0.027 & 0.027 \\
\hline
\end{tabular}

Our analysis shows that the proportion of deliberate underpricing is the dominant component, when compared to aftermarket mispricing, and explains, at least to some extent, the variation in the overall initial return. These findings provide evidence in support of the IPO information asymmetry literature and the resulting pricing inefficiencies. The presence of pricing inefficiencies is not a challenge to the efficient market hypothesis, but rather a confirmation that information asymmetry between firm insiders, outside investors, and professional advisers in the primary market will lead to deliberate underpricing.

\subsection{Explaining aftermarket mispricing}

Table 6 confirms that aftermarket mispricing is significantly influenced by trading volume in IPO shares after the first day of trading, the price adjustment between the filing price range and the offer price to reflect investor demand in shares, equity retained by pre-IPO owners in the post-IPO firm, underwriter reputation, and offer size. As discussed below, our findings support earlier studies, although we note that the studies quoted below all use initial return compared to our more refined aftermarket mispricing measure.

Trading volume in the aftermarket captures the demand for shares in the secondary market. Our findings show that demand and aftermarket mispricing are positively correlated and hence consistent with those reported in Aggarwal (2000, 2003), Ellis, Michaely and O'Hara $(2000,2002)$ and Ellis (2006). IPOs for which the offer price is above the initial filing price range have, on average, higher aftermarket mispricing. The price revision is likely to capture the demand for shares revealed during the marketing phase of an IPO. Our findings are consistent with those reported in Hanley (1993) and Ellis (2006). Equity retained has a negative association with aftermarket mispricing. ${ }^{13} \mathrm{~A}$ higher proportion of equity retained will limit the number of shares available for trading. Accordingly, lower levels of free float will create excess demand in shares available for trading and hence will result in an increase in share prices. Our findings are consistent

\footnotetext{
13 The non-linear data transformation on equity retained, RET, into $\hat{\alpha}=R E T+\ln (1-R E T)$ means that the larger the negative value of $\hat{\alpha}$ the higher the proportion of equity retained.
} 
with the evidence reported in Chen, Hung and Wu's (2002) analysis. Therefore, equity retained seems to be able to explain aftermarket mispricing rather than deliberate premarket underpricing, in contradiction to the signalling argument.

\section{Table 6: Mispricing in the early aftermarket}

Estimates of aftermarket mispricing and deliberate premarket underpricing rely on the model definitions used in Table 4. Aftermarket mispricing is the dependent variable.

\begin{tabular}{lcccccc}
\hline Independent Variables & $(1)$ & $(2)$ & $(3)$ & $(4)$ & $(5)$ & $(6)$ \\
\hline \% of Shares Traded & $0.356^{* * *}$ & $0.415^{* * *}$ & $0.415^{* * *}$ & $0.417^{* * *}$ & $0.416^{* * *}$ & $0.413^{* * *}$ \\
& $(0.018)$ & $(0.020)$ & $(0.020)$ & $(0.020)$ & $(0.020)$ & $(0.020)$ \\
Above Filing Range & $10.970^{* * *}$ & $11.453^{* * *}$ & $11.490^{* * *}$ & $11.406^{* * *}$ & $11.457^{* * *}$ & $11.777^{* * *}$ \\
& $(2.329)$ & $(2.712)$ & $(2.715)$ & $(2.719)$ & $(2.716)$ & $(2.712)$ \\
Below Filing Range & -3.036 & -3.661 & -3.758 & -3.780 & -3.726 & -3.939 \\
& $(2.364)$ & $(2.851)$ & $(2.854)$ & $(2.858)$ & $(2.855)$ & $(2.852)$ \\
Equity Retained & $-7.799^{* * *}$ & $-9.155^{* * *}$ & $-9.191^{* * *}$ & $-9.145^{* * *}$ & $-9.285^{* * *}$ & $-9.246^{* * *}$ \\
& $(2.402)$ & $(2.809)$ & $(2.812)$ & $(2.816)$ & $(2.813)$ & $(2.810)$ \\
Underwriter Reputation & -0.794 & $2.257^{* * *}$ & $2.365^{* * *}$ & $2.346^{* * *}$ & $2.378^{* * *}$ & $2.381^{* * *}$ \\
& $(0.622)$ & $(0.761)$ & $(0.762)$ & $(0.763)$ & $(0.763)$ & $(0.762)$ \\
Offer Size & 0.433 & $6.676^{* * *}$ & $6.564^{* * *}$ & $6.601^{* * *}$ & $6.539^{* * *}$ & $6.561^{* * *}$ \\
& $(0.899)$ & $(1.080)$ & $(1.082)$ & $(1.083)$ & $(1.082)$ & $(1.081)$ \\
Constant & $-16.626^{* * *}$ & $-76.023^{* * *}$ & $-76.642^{* * *}$ & $-76.845^{* * *}$ & $-76.798^{* * *}$ & $-76.818^{* * *}$ \\
& $(4.184)$ & $(5.108)$ & $(5.114)$ & $(5.121)$ & $(5.116)$ & $(5.109)$ \\
\hline Observations & 1577 & 1334 & 1334 & 1334 & 1334 & 1334 \\
$\mathrm{R}^{2}$ & 0.320 & 0.420 & 0.420 & 0.421 & 0.421 & 0.420 \\
\hline
\end{tabular}

${ }^{*} \mathrm{p}<0.10,{ }^{* *} \mathrm{p}<0.05,{ }^{* * *} \mathrm{p}<0.01$. Standard errors are in parentheses.

IPOs brought to market by more reputable underwriters are subject to greater aftermarket mispricing. This finding suggests that more reputable underwriters are more likely to provide price support in the early aftermarket. Price support leads to a censoring of aftermarket mispricing distribution. Our evidence is therefore consistent with Ruud (1993), Asquith, Jones and Kieschnick (1998) and Aggarwal (2000, 2003). Offer size has a positive association with aftermarket mispricing. This finding does not support the notion that investors perceive smaller IPOs as riskier compared to larger new issues of more established companies. Our evidence contradicts the findings reported in Beatty and Ritter (1986), Ritter (1987), and Carter (1992).

\section{Conclusion}

Our paper makes several contributions to the literature in light of the ongoing debate on whether deliberate premarket underpricing or aftermarket mispricing is the dominant explanation of observed initial return. First, we add to the scarce literature on the use of SFA as a tool for disentangling deliberate premarket underpricing from initial return. Using data on a sample of U.S. IPOs, we estimate a stochastic IPO pricing frontier, distinguishing between pricing factors and underpricing factors to estimate the maximum (fair) offer price. Pricing factors are the primary drivers of equity value and our paper employs a larger set of pricing factors compared to earlier 
studies. This allows us to provide more reliable estimates of the maximum (fair) offer price and estimates of deliberate premarket underpricing. Our estimation returns deliberate premarket underpricing averaging at $14 \%$. This compares to observed average initial return of $19.1 \%$. In a separate regression of initial returns on deliberate underpricing, we find that a portion of initial return can be explained by deliberate premarket underpricing.

Second, we use our refined measure of deliberate underpricing to test the commonly held view that information asymmetry surrounding IPO value among new issues market participants explains variations in deliberate underpricing. Existing empirical studies that seek to explain initial return do not distinguish between deliberate premarket underpricing and aftermarket mispricing, which could potentially make their findings less robust by assigning different weights to these explanatory factors. We therefore provide new insights into the validity of existing theory and empirical studies. We proxy information asymmetry by variables capturing ex ante uncertainty surrounding firm attributes, deal characteristics, third-party certification, IPO market conditions, and private firms' demand for capital. Our empirical exercise reveals only partial support for a joint signalling effect of equity retained by pre-IPO owners in the post-IPO firm and the proceeds at the disposal of the issuer. We present evidence that equity retained is an unlikely signalling mechanism to convey firm value to outside investors through deliberate premarket underpricing. New issues market conditions are not found to impact on deliberate premarket underpricing. The impact of new issues market conditions has not attracted any attention in existing studies using a SFA framework. Our findings also indicate lower average underpricing during periods of 'hot' demand for private firms' capital and show that 'cold' periods for private firms' demand for capital have lower average underpricing. This evidence is somewhat surprising and would suggest that any exogenous shock leads to a lower average underpricing and deserves future investigation in other stock markets.

Finally, once we have estimated the deliberate underpricing component, we are then able to recover an estimate of aftermarket mispricing, which we then test against proxies of trading activity, allowing us to test the hypothesis that IPO market value partly depends on the trading activity in the early aftermarket. We find evidence that aftermarket mispricing is affected by trading volume in IPO shares on the first day of trading, the price adjustment between the filing price range and the offer price to reflect investors' demand for shares, equity retained by original owners, underwriter reputation, and offer size.

Our analysis reveals that deliberate underpricing is the more dominant component that makes up initial return when compared to the fraction of aftermarket mispricing. Deliberate underpricing is identical to the pricing inefficiency in our SFA analysis. This pricing inefficiency is not a challenge to the efficient market hypothesis in which prices quickly and accurately adjust to a new equilibrium as a result of trading, but instead confirms that information asymmetry between new 
issues market participants surrounding firm value in the primary market will lead to deliberate underpricing in the absence of trading. Our proxy variables that capture information asymmetry at different stages of the flotation process explain a large fraction of the variation in estimated deliberate underpricing across estimation models.

While outside investors benefit from deliberate underpricing, issuers leave money on the table which could potentially leave the IPO market subject to Akerlof's (1977) classic adverse selection problem. This adverse selection problem could lead to an inefficient functioning of the IPO market and - at the extreme - to market failure if IPO firms completely withdraw from the new issues market if deliberate underpricing reaches unsustainable levels. If issuers have to leave an excessive amount of money on the table, then firms might seek an alternative way to exit from their investment or other means of raising capital.

Our study implies that new issues market participants can to some extent influence aspects of information asymmetry at different stages of the flotation process and hence deliberate underpricing, while other aspects are beyond the direct control of market participants. On the one hand, issuing firm attributes such as, for example, the amount of sales in the accounting period before flotation or firm age are factors beyond the direct control of issuers at the time of flotation. On the other hand, issuers appear to be able to more directly influence deliberate underpricing through decisions and actions relating to deal characteristics, third-party certification, and possibly market timing. For example, the presence of lock-in agreements by pre-IPO owners increases the level of demand for the shares and hence underpricing, while having no lock-in agreements increases information asymmetry between firm insiders and outside investors. Underwriter fees will be higher for those IPOs for which relatively little public information is available. Therefore, more direct disclosure by issuers during the flotation process will lead to lower levels of information asymmetry among new issues market participants and ultimately lower underpricing for IPOs of identical levels of business and financial risk. An ability to take actions by market participants to influence the level of deliberate underpricing is important for the new issues market to continue functioning and to reduce the possibility of an adverse selection problem to minimize the danger of a complete withdrawal of all IPO firms from this market. 


\section{Bibliography}

Aigner, Dennis J., C.A. Knox Lovell and Peter Schmidt, 1977, Formulation and estimation of Stochastic Frontier Production Function Models, Journal of Econometrics 6, 21-37.

Aggarwal, Rajesh, Sanjai Bhagat, and Srinivasan Rangan, 2009, The impact of fundamentals on IPO valuation, Financial Management 38, 253-284.

Aggarwal, Reena, 2000, Stabilization activities by underwriters after initial public offerings, Journal of Finance 55, 1075-1103.

Aggarwal, Reena, 2003, Allocation of initial public offerings and flipping activity, Journal of Financial Economics 68, 111-135.

Aggarwal, Reena, and Pietra Rivoli, 1990, Fads in the initial public offering market?, Financial Management: The Journal of the Financial Management Association 19, 45-57.

Akerlof, George A., 1970, The market for "lemons": Quality uncertainty and the market mechanism, Quarterly Journal of Economics 84, 488-500.

Allen, Franklin, and Gerald R. Faulhaber, 1989, Signalling by underpricing in the IPO market, Journal of Financial Economics 23, 303-323.

Arthurs, Jonathan D., Lowell W. Busenitz, Robert E. Hoskisson, and Richard A. Johnson, 2009, Signaling and initial public offerings: The use and impact of the lockup period, Journal of Business Venturing 24, 360-372.

Asquith, Daniel, Jonathan D. Jones, and Robert Kieschnick, 1998, Evidence on price stabilization and underpricing in early IPO returns, Journal of Finance 53, 1759-1773.

Banerjee, Suman, Lili Dai, and Shrestha Keshab, 2011, Cross-country IPOs: what explains differences in underpricing?, Journal of Corporate Finance 17, 1289-1305.

Baron, David P., 1982, A model of the demand for investment banking advising and distribution services for new issues, Journal of Finance 37, 955-976.

Barry, Christopher B., Chris J. Muscarella, I. I. I. John W. Peavy, and Michael R. Vetsuypens, 1990, The role of venture capital in the creation of public companies: Evidence from the going-public process, Journal of Financial Economics 27, 447-471.

Bartling, Björn, and Andreas Park, 2009, What determines the level of IPO gross spreads? Underwriter profits and the cost of going public, International Review of Economics \& Finance 18, 81-109.

Beatty, Randolph P., and Jay R. Ritter, 1986, Investment banking, reputation, and the underpricing of initial public offerings, Journal of Financial Economics 15, 213-232.

Beatty, Randonlph P., Howard Bunsis, and John R. M. Hand, 1998, The indirect economic penalties in SEC investigations of underwriters, Journal of Financial Economics 50, 151-186. 
Booth, James R., and Richard L. Smith, 1986, Capital raising, underwriting and the certification hypothesis, Journal of Financial Economics 15, 261-281.

Bradley, Daniel J., Bradford D. Jordan, Yi Ha-Chin, and Ivan C. Roten, 2001, Venture capital and IPO lockup expiration: An empirical analysis, Journal of Financial Research 24, 465-493.

Brailsford, Tim, Richard Heaney, and Jing Shi, 2004, Modelling the behaviour of the new issue market, International Review of Financial Analysis 13, 119-132.

Brav, Alon, and Paul A. Gompers, 1997, Myth or reality? The long-run underperformance of initial public offerings: Evidence from venture and nonventure capital-backed companies, Journal of Finance 52, 1791-1821.

Brav, Alon, and Paul A. Gompers, 2003, The role of lockups in initial public offerings, Review of Financial Studies 16, 1-29.

Carter, Richard B., 1992, Underwriter reputation and repetitive public offerings, Journal of Financial Research 15, 341-354.

Carter, Richard B., and Steven Manaster, 1990, Initial public offerings and underwriter reputation, Journal of Finance 45, 1045-1068.

Carter, Richard B., and Frederick H. Dark, 1993, Underwriter reputation and initial public offers: The detrimental effects of flippers, The Financial Review 28, 279-301.

Carter, Richard B., and Frederick H. Dark, 1990, The use of the over-allotment option in initial public offerings of equity: Risks and underwriter prestige, Financial Management 19, 55-64.

Carter, Richard B., Frederik H. Dark, and Ajai K. Singh, 1998, Underwriter reputation, initial return, and the long-run performance of IPO stocks, Journal of Finance 53, 285-311.

Chahine, Salim, 2007, Investor interest, trading volume, and the choice of IPO mechanism in France, International Review of Financial Analysis 16, 116-135.

Chan, Yue-Cheong, Congsheng Wu, and Chuck Kwok, 2007, Valuation of global IPOs: A stochastic frontier approach, Review of Quantitative Finance \& Accounting 29, 267-284.

Chemmanur, Thomas J., and Imants Paeglis, 2005, Management quality, certification, and initial public offerings, Journal of Financial Economics 76, 331-368.

Chen, Anlin, Chen Dhein Hung, and Chin-Shun Wu, 2002, The underpricing and excess returns of initial public offering in Taiwan based on noisy trading: A stochastic frontier model, Review of Quantitative Finance \& Accounting 18, 139-159.

Deeds, David L., Dona Decarolis, and Joseph E. Coombs, 1997, The impact of firm specific capabilities on the amount of capital raised in an initial public offering: Evidence from the biotechnology industry, Journal of Business Venturing 12, 31-46.

Downes, David H., and Robert Heinkel, 1982, Signaling and the valuation of unseasoned new issues, Journal of Finance 37, 1-10. 
Ellis, Katrina, 2006, Who trades IPOs? A close look at the first days of trading, Journal of Financial Economics 79, 339-363.

Ellis, Katrina, Roni Michaely, and Maureen O'Hara, 2000, When the underwriter is the market maker: An examination of trading in the IPO aftermarket, Journal of Finance 55, 1039-1074.

Ellis, Katrina, Roni Michaely, and Maureen O'Hara, 2002, The making of a dealer market: From entry to equilibrium in the trading of NASDAQ stocks, Journal of Finance 57, 2289-2316.

Fama, Eugene F., and Kenneth R. French, 1997, Industry costs of equity, Journal of Financial Economics 43, 153-193.

Field, Laura Casares, and Gordon Hanka, 2001, The expiration of IPO share lockups, Journal of Finance 56, 471-500.

Francis, Bill B., and Iftekhar Hasan, 2001, The underpricing of venture and nonventure capital IPOs: An empirical investigation, Journal of Financial Services Research 19, 99-113.

Friesen, Geoffrey C., and Christopher Swift, 2009, Overreaction in the thrift IPO aftermarket, Journal of Banking \& Finance 33, 1285-1298.

Gompers, Paul A., 1996, Grandstanding in the venture capital industry, Journal of Financial Economics 42, 133-156.

Grinblatt, Mark, and Chuan Yang Hwang, 1989, Signalling and the pricing of new issues, The Journal of Finance 44, 393-420.

Habib, Michel A., and Alexander P. Ljungqvist, 2001, Underpricing and entrepreneurial wealth losses in IPOs: Theory and evidence, Review of Financial Studies 14, 433-458.

Hanley, Kathleen Weiss, 1993, The underpricing of initial public offerings and the partial adjustment phenomenon, Journal of Financial Economics 34, 231-250.

Hertzel, Michael G., Mark R. Huson, and Robert Parrino, 2012, Public market staging: The timing of capital infusions in newly public firms, Journal of Financial Economics 106, 72-90.

Hsuan-Chi, Chen, and Jay R. Ritter, 2000, The seven percent solution, Journal of Finance 55, 1105-1131.

Hughes, Patricia J., 1986, Signalling by direct disclosure under asymmetric information, Journal of Accounting and Economics 8, 119-142.

Hunt-McCool, Janet, Samuel C. Koh, and Bill B. Francis, 1996, Testing for deliberate underpricing in the IPO premarket: A stochastic frontier approach, Review of Financial Studies 9, 1251-1269.

Jenkinson, Tim, and Alexander Ljungqvist, 2001, The role of hostile stakes in German corporate governance, Journal of Corporate Finance 7, 397-446.

Kim, Moonchul, and Jay R. Ritter, 1999, Valuing IPOs, Journal of Financial Economics 53, 409437. 
Kim, Woojin, and Michael S. Weisbach, 2008, Motivations for public equity offers: An international perspective, Journal of Financial Economics 87, 281-307.

Koop, Gary, and Kai Li, 2001, The valuation of IPO and SEO firms, Journal of Empirical Finance 8, 375-401.

Krishnan, C. N. V., Vladimir I. Ivanov, Ronald W. Masulis, and Ajai K. Singh, 2011, Venture capital reputation, post-IPO performance, and corporate governance, Journal of Financial \& Quantitative Analysis 46, 1295-1333.

Kumbhakar, S. C. and K. C. A. Lovell, 2000, Stochastic Frontier Analysis, Cambridge University Press: Cambridge.

Leland, Hayne E., and David H. Pyle, 1977, Informational asymmetries, financial structure, and financial intermediation, Journal of Finance 32, 371-387.

Leone, Andrew J., Steve Rock, and Michael Willenborg, 2007, Disclosure of intended use of proceeds and underpricing in initial public offerings, Journal of Accounting Research 45, 111-153.

Lerner, Joshua, 1994, Venture capitalists and the decision to go public, Journal of Financial Economics 35, 293-316.

Liu, Xiaoding, and Jay R. Ritter, 2011, Local underwriter oligopolies and IPO underpricing, Journal of Financial Economics 102, 579-601.

Liu, Yanyan, and Robert Myers, 2009. Model selection in stochastic frontier analysis with an application to maize production in Kenya. Journal of Productivity Analysis 31, 33-46.

Ljungqvist, Alexander L., and Jr Williamj Wilhelm, 2003, IPO pricing in the dot-com bubble, Journal of Finance 58, 723-752.

Loughran, Tim, and Jay Ritter, 2004, Why has IPO underpricing changed over time?, Financial Management 33, 5-37.

Loughran, Tim, Jay R. Ritter, and Kristian Rydqvist, 1994, Initial public offerings: International insights, Pacific-Basin Finance Journal 2, 165-199.

Loughran, Tim, and Jay R. Ritter, 1995, The new issues puzzle, Journal of Finance 50, 23-51.

Lowry, Michelle, and G. William Schwert, 2002, Ipo market cycles: Bubbles or sequential learning?, Journal of Finance 57, 1171-1199.

Lowry, Michelle, 2003, Why does IPO volume fluctuate so much?, Journal of Financial Economics 67, 3-40.

Luo, Changqing, and Zisheng Ouyang, 2014, Estimating IPO pricing efficiency by Bayesian stochastic frontier analysis: The ChiNext market case, Economic Modelling 40, 152-157.

Megginson, William L., and Kathleen A. Weiss, 1991, Venture capitalist certification in initial offerings, Journal of Finance 46, 879-903. 
Meeusen, W. and J. van de Broeck, 1977, Efficiency estimation from cobb-douglas production functions with composed errors, International Economic Review 18, 435-444.

Nahata, Rajarishi, 2008, Venture capital reputation and investment performance, Journal of Financial Economics 90, 127-151.

Nanda, Ramana, and Matthew Rhodes-Kropf, 2013, Investment cycles and startup innovation, Journal of Financial Economics 110, 403-418.

Peng, Yahui, and Kehluh Wang, 2007, IPO underpricing and flotation methods in Taiwan - a stochastic frontier approach, Applied Economics 39, 2785-2796.

Purnanandam, Amiyatosh K., and Bhaskaran Swaminathan, 2004, Are IPOs really underpriced?, Review of Financial Studies 17, 811-848.

Ritter, Jay R., 1984a, The 'hot issue' market of 1980, Journal of Business 57, 215-240.

Ritter, Jay R., 1984b, Signaling and the valuation of unseasoned new issues: A comment, Journal of Finance 39, 1231-1237.

Ritter, Jay R., 1987, The costs of going public, Journal of Financial Economics 19, 269-281. 27.

Ritter, Jay R., 1991, The long-run performance of initial public offerings, Journal of Finance 46, 3-

Ritter, Jay, 2003, Investment banking and securities issuance, Chapter 5, in George Constantinides, Milton Harris, and René Stulz, eds.: Handbook of the economics of finance (NorthHolland).

Roosenboom, Peter, and Tjalling van der Goot, 2005, The effect of ownership and control on market valuation: Evidence from initial public offerings in The Netherlands, International Review of Financial Analysis 14, 43-59.

Rock, Kevin, 1986, Why new issues are underpriced, Journal of Financial Economics 15, 187-212.

Ruud, Judith S., 1993, Underwriter price support and the IPO underpricing puzzle, Journal of Financial Economics 34, 135-151.

Spence, Michael, 1973, Job market signaling, Quarterly Journal of Economics 87, 355-375.

Teoh, Stew Hong, Ivo Welch, and T. J. Wong, 1998, Earnings management and the long-run market performance of initial public offerings, Journal of Finance 53, 1935-1974.

Welch, Ivo, 1989, Seasoned offerings, imitation costs, and the underpricing of initial public offerings, Journal of Finance 44, 421-449.

Yung, Chris, Gönül Çolak, and Wang Wei, 2008, Cycles in the IPO market, Journal of Financial Economics 89, 192-208. 